\title{
Öğrenme Amaçlı Yazma Etkinliklerinin Ortaokul 6. Sınıf Öğrencilerinin Madde ve Isı Ünitesindeki Kavramsal Anlamalarına Etkisi
}

\section{The Effect of Writing-to-Learn Strategies on 6 Grade Students' Conceptual Understanding of Matter and Heat Unit}

\author{
Fatma YAMAN ${ }^{*}$
}

\section{Toplumsal Mesaj.}

Bu çalışma ile öğrenme amaçlı yazma etkinlikleri olan argümantasyon ve özet yazma etkinliklerinin öğrencilerin fen konularını öğrenmeleri üzerindeki etkisi incelenmiştir. Elde edilen sonuçlar öğrencilerin dili etkin bir şekilde kullanabilmeleri için fen kavramlarını başkalarını ikna etmede kullanmaları ve öğretmenden farklı bir muhataba bu konuları bilgilendirme amaçlı yazmaları gerektiğini göstermiştir.

Anahtar Kelimeler: Argümantasyon tabanlı bilim öğrenme yaklaşımı, öğrenme amaçlı yazma etkinlikleri, kavramsal anlama.

Abstract. This study investigated the effect of two different writing-to-learn strategies-argumentative and summary writing- on students' conceptual understanding. A quasi experimental study was conducted in the study and 846 th graders, 43 of which were in the control group, and 41 of which were in the experimental group participated the study. While the students in control group were implemented traditional laboratory, the ones in the experimental group were implemented the Science Writing Heuristic approach, which is an immersive approach to argument-based inquiry. After unit teaching, students in all groups were asked to write a summary writing activity. The activities were performed on matter and heat unit in the curriculum of 6 grade level. A two-tier test was used as a pre and post-test and a rubric developed for students' summary writing activities was used to evaluate their conceptual understanding. Data were analyzed using Kruskal Wallis test. The results indicated that students in the experimental group had significantly better conceptual understanding and performed better on summary writing activities while compared with traditional group students. The students should be provided with opportunities to help them engage with writing activities that require students to convince the others about what the conceptual ideas mean within the topic and to inform the others about these concepts and how these are related with each other.

Keywords: Argument-based inquiry approach, writing-to-learn strategies, conceptual understanding.

\section{Public Interest Statement.}

This study investigated the effect of two different writingto-learn strategiesargumentative and summary writing- on students' learning related to science concepts. The results indicated that to be able to learn better students need to use language effectively to write to others to convince them and write to inform to an audience other than their teacher.

\footnotetext{
* Orcid ID: http://orcid.org/0000-0002-4014-3028, Dr. Öğr. Üyesi, Yozgat Bozok Üniversitesi, Matematik ve Fen Bilimleri Eğitimi Bölümü, Fen Bilgisi Eğitimi ABD; fatma.yaman@bozok.edu.tr 


\section{GiRiş}

Son yıllarda yapılan çalışmalar ile dilin, bilim ve fen okuryazarlı̆̆ ve fen uygulamalarının bütünleştirici bir parçası olduğu vurgulanmaktadır (Hand, McDermott ve Prain, 2016; Hand, Norton-Meier ve Jang, 2017; Hand, Shelley, Laugerman, Fostvedt ve Therrien, 2018; Jang ve Hand, 2017; Yore, Florence, Pearson ve Weaver, 2006). Norris ve Phillips'in (2003) vurguladığı gibi dil, fenin öğretilmesinde vazgeçilmez bir öneme sahiptir ve fenin öğrenilmesi dil (metin, grafik, resim, şekil, denklemler, matematiksel ve kimyasal eşitlikler, işaret dili) olmadan gerçekleşmemektedir. Ayrıca, dilin bilimsel bilginin inşaasında anahtar bir role sahip olduğu, fen ile ilgili iletişimi sağladığı ve fen uygulamalarında bir öğrenme aracı olduğu vurgulanmaktadır (Galbraith, 1999; Ford ve Forman 2006; Norris ve Phillips, 2003). Bu gelişmeleri göz önünde bulunduran fen eğitimcileri, fenin öğrenilmesi ve uygulanmasında dilin önemini yeniden gözden geçirmektedir (Hand, McDermott ve Prain, 2016; Hand, Shelley, Laugerman, Fostvedt ve Therrien, 2018; Yore ve diğerleri, 2006).

Dil kullanımı, okuma, yazma, konuşma ve dinlemeyi gerektirmektedir. Yapılan araştırmalar bilimsel bilginin inşa edilmesi ve öğrencilerin fendeki anlamalarının oluşturulması sürecinde yazmanın bir öğrenme aracı olarak kullanılması gerektiğini vurgulamıştır (Hand, 2017; Hand, Wallace ve Yang, 2004; Jang ve Hand, 2017). Cavagnetto, Hand ve Norton-Meier (2009), öğrencilerin grup çalışması esnasında, yazma etkinliklerini kullanarak kavramsal anlamalarının oluşabileceğini savunmuştur. Bu bağlamda, öğrencilerin, feni kendi yaptıkları araştırmaları yazılı ve sözlü formlarda bilimsel argüman oluştururken öğrendikleri ifade edilmektedir (Driver, Newton ve Osborne, 2000). Bilimsel argüman oluşturma ve öğrenmede dilin kritik bir öneme sahip olduğunu savunan Cavagnetto ve Hand (2012), argümantasyonun bilimsel bilginin oluşturulmasını sağladığını ve dil kullanımı aracılığıyla ilerlediğini vurgulamaktadır. Bilimsel argümantasyon en genel anlamda bilim alanında ya da farklı alanlarda ikna edici argümanların geliştirildiği, gerekçelendirmelerin yapıldı̆̆ı, kanıt ve teorik fikirler arasındaki ilişkiler vasıtasıyla geçerli argümaların oluşturulduğu öğrenme süreci olarak tanımlanmaktadır (Aktamış ve Hiğde, 2015). Fen eğitiminde, argümantasyon ile ilgili yapılan çalışmaların çoğunluğu Toulmin'in argüman yapısı (veri, iddia, gerekçe, destekleyiciler, niteleyiciler, çürütme) dikkate alınarak yapııırken (Jang ve Hand, 2017), bu yapının sınıf ortamındaki küçük grup tartışmalarındaki argümanları analiz etmede başarısız olduğu ifade edilmektedir (Aktamış ve Hiğde, 2015). Toulmin modelinin alan bağımsız olması ve uygulamadaki bazı eksikliklerinden dolayı fen eğitiminde alan bağımlı argümantasyon modelleri ortaya atılmıştır (Aktamış ve Hiğde, 2015; Duschl, 2007). Bu bağlamda, Samspson ve Clark (2006) argümanların değerlendirilmesinde Toulmin, Zohar ve Nemet, Kelly ve Takao, Sandoval, ve Lawson'un argüman yapısını incelemiş ve bilimsel argüman kalitesinin değerlendirilmesi için beş kriter önermiştir. Bu kriterler; "iddiaların niteliğinin ve doğallı̆ının incelenmesi, iddianın nasıl doğrulandığının incelenmesi, bir iddianın bütün mevcut kanıtlar için geçerli olup olmadığının incelenmesi, argümanın alternatif açıklamaları nasıl çürüttüğünün incelenmesi, epistemik kaynakların iddia ve kanıtların koordine edilmesinde nasıl kullanılacağının incelenmesi" şeklinde ifade edilmektedir. Duschl (2007), Sampson ve Clark tarafından ortaya konan bu beş kriterin incelenmesinde Walton'un argüman yapısının yardımcı olacağını iddia etmiştir. Bu çalışma kapsamında kullanılan argüman yapısı Walton'ın argüman yapısını temel almaktadır. Illgili alanyazın incelendiğinde öğrencilerin hem sözlü hem de yazılı argümantasyonlarının geliştirilmesine ve dili fen sınıflarında aktif bir şekilde kullanmasına yardımcı olan çalışmalara intiyaç duyulmaktadır. Bu bağlamda, bu çalışmada öğrencilerin dili aktif bir şekilde kullanabilecekleri iki farklı öğrenme amaçlı yazma etkinliği olan özet yazma (açıklamaya dayalı yazma) ve argümantasyona dayalı yazma etkinlikleri üzerine odaklanmıştır.

\section{1 Öğrenme amaçlı yazma stratejileri}

Öğrenme amaçlı yazma stratejileri, fenin bir disiplin olarak anlaşılmasına ve çalışılan konu hakkında öğrencilerin zengin anlamlar oluşturmasına yardım etmektedir. Yazma, ileşitim aracı olarak kullanıımasının yanısıra son zamanlarda öğrencilerin fen okuryazarlığının artması ve kavramsal anlamalarının (epistemik) gelişmesi için bir araç olarak da kullanılmaktadır (McDermott ve Hand, 2006; Yore ve Treagust, 2006). Fen sınıflarında öğrenme amaçlı yazma konusunda geleneksel ve 
geleneksel olmayan yazma olmak üzere iki farklı görüş bulunmaktadır (Prain, 2006). Bu bağlamda, geleneksel yazma etkinlikleri okullarda uygulanan geleneksel laboratuvar raporu yazma formatını içerirken, geleneksel olmayan yazma etkinlikleri hikayeler, mektuplar, broşürler vs gibi yazma etkinliklerini içermektedir (McDermott ve Hand, 2006; Prain, 2006). Geleneksel yazma etkinlikleri, bilim insanlarının yaptıklarını tekrar ederek onların ürettikleri yazma formatını (amaç, deneyin yapılışı, gözlemler ve veriler, sonuçlar ve tartışma) kullanmaktadır. Bu çeşit bir yazma etkinliğinde yazma, bilgilerin anlatıldı̆̆ı ve var olan bilgilerin geri çağrıldığı bir süreç olarak görülmekte ve mevcut bilgilerin değişmediği iddia edilmektedir (Bereiter ve Scardamalia,1987; Hand, 2007). Diğer taraftan, geleneksel olmayan yazma etkinliklerinde öğrenciler bilimsel bilgileri sınıfta uyguladıkları bilgilerin ötesinde kullanmakta, bilimsel bilgilerin anlamlarını daha derinlemesine incelemekte ve kavramları yeniden yapılandırmaktadır. Bu tür yazma etkinliklerinde yazma, yazarın içerik ve retorik (sözbilim) bilgisi arasındaki etkileşimden ötürü bilginin yapılandırılığı, yeni bilginin oluşturulduğu bir süreç olarak görülmektedir (Galbraight, 1999; Hand, 2007). Ayrıca, ilgili alan yazın, öğrencilerin fen sınıflarında geleneksel olmayan yazma etkinlikleri kullandıklarında daha iyi bir kavramsal anlamaya sahip olduğunu göstermektedir (Günel, Hand ve Prain, 2007; Günel, Hand ve McDermott, 2009; Hohensell ve Hand, 2006). Prain ve Hand (1996) fen sınıflarında öğrenme amaçlı yazma etkinliklerinin kullanılması için beş bileşenden oluşan bir model önermiştir. Önerilen bileşenler; yazma türü, konu, amaç, metin üretimi yöntemi ve muhataptır. Modelde ifade edilen "yazma türü", günlük, hikaye, mektup, gezi yazısı vs olabilirken "konu" olarak anahtar kavramların açıklanması seçilebilmektedir. Yazma etkinliğinde "muhatap" olarak akranlar, ebeveynler, öğretmenler, genç yaştaki muhataplar (örneğin, 11. sınıftaki bir öğrencinin 6. sınıftaki bir öğrenciye yazması) alınmaktadır. Öğrenciler, bilgisayar ya da kalem kullanarak yazma etkinliklerini bireysel ya da grup olarak hazırlayabilirler (üretim metodu). Bileşende ifade edilen amaç, araştırma yaparak düşünceyi keşfetme olabileceği gibi, konu hakkında bildiğini açıklamak, konu hakkında bildiklerini başkalarına yansıtarak ikna etmek şeklinde de olabilir. Yazma modelindeki her bir bileşen birbirinden ayrı olarak görülebilir; ancak, bunlar birbiriyle bağlantılı olarak kullanılmaktadır. Örneğin, amaç ünite sonunda konuyu özetlemek ise, yapılan bu yazma etkinliğinin daha genç yaştaki bir muhataba yazııması daha uygundur. Bunu yaparken, sınıf tartışmasının (metin üretim yöntemi) ardından bireysel olarak hikaye (yazma türü) yazılabilir (Hand, 2017).

Prain ve Hand (1996) tarafından önerilen modelin bu çalışma kapsamında önemli olan iki bileşeni "muhatap ve amaç" tır. Öğrencilerin yazma etkinlikleri üzerinde farklı muhatabın etkisini inceleyen çalışmada Günel ve diğerleri (2009), lise öğrencilerinden kendilerinden yaşça daha küçük bir muhataba ve öğretmene yazma etkinlikleri yapmaları istenmiştir. Çalışma sonucunda biyolojideki kavramsal soruların cevaplanmasında daha genç bir muhataba yazma etkinlikleri yazan grubun, öğretmene yazma etkinlikleri yazan gruptan istatistiksel olarak daha anlamlı sonuçlar elde ettiğini rapor etmiştir. Hand ve arkadaşları (Chen, Hand ve McDowell, 2013; Hand, Hohenshell ve Prain, 2007; Hand ve Prain, 2006; McDermott ve Hand, 2010) özet yazma etkinliklerini öğrencilerden öğretmene yazmalarını istendiğinde, öğrencilerin genel olarak bilimsel kavramları bilimsel kaynaklarda yazıldığı şekliyle kullandıklarını ve öğretmenden onları anlamalarını bekledikleri vurgulamıştır. Bunun aksine, daha genç bir muhataba yazmaları istendiğinde öğrencilerin bu bilimsel kavramları ilk önce günlük dile, sonrasında ise muhatabın anlayacağı dile çevirdiklerini ve etkinliğin doğası gereği öğrencilerin konuyu daha önceki anladıklarından farklı bir şekilde anladıkları, böylelikle bilgiyi yenideninşa ettikleri (Galbraight, 1999) ifade edilmiştir. Bu durum öğrenme amaçlı yazma etkinliklerinin epistemik bir araç olduğunu göstermektedir (Prain ve Hand, 2016). Ayrıca, yapılan çalışmalar daha genç bir muhataba yazmanın zihinsel olarak çaba gerektiren bir durum olduğunu vurgulamıştır (Lamb, Hand ve Yoon, 2017; Mcdermott ve Hand, 2010).

\subsection{Argümantasyon Tabanlı Bilim Öğrenme Yaklaşımı}

Argümantasyon tabanlı bilim öğrenme (ATBÖ) Hand ve Keys (1999) tarafından dilin bilimsel argümantasyon inşa edilirken bir araç olarak kullanıldığı bir yaklaşımdır. Ülkemizde bu yaklaşımın öğrenci ve öğretmen şablonu yapılan çalışmalarda kullanılmaktadır (Kıngır, Geban ve Günel, 2012, 
2013); ancak, son yıllarda Hand ve arkadaşları (Hand, Norton-Meier ve Jang, 2017; Hand, Shelley, Laugerman, Fostvedt ve Therrien, 2018) bu yaklaşımın son halini Tablo 1'de gösterildiği şekliyle daha geniş bir perspektiften sunmuştur. Bu yaklaşım "epistemik çatının altında yatanların geliştirilmesi", "argüman fazı" ve "özet yazma fazı" olmak üzere üç fazdan oluşmaktadır.

Fendeki "epistemik çatının altında yatanların geliştirilmesi fazı", bilimsel uygulamaların gelişimine ve öğrenmenin fendeki büyük fikirler etrafında nasıl çerçevelendiğinin anlaşılmasına dayanmaktadır. Bu faz, ayrıca, dilin önemini, argümanın yapı ve uygulamalarını, öğrencilerin ön bilgilerinin belirlenmesini, müzakerelerin önemini ve öğrenmede grup rolünü vurgulamaktadır (Hand ve diğerleri, 2017; 2018).

"Argüman fazı", araştırma ve fen ile ilgili öğrenmelerin gerçekleştiği fazdır (Hand ve diğerleri, 2017; 2018). Bu faz, soru, iddia ve kanıt yapısı etrafında çerçevelenmiştir ve Walton'un (2016) argüman yapısını merkeze almaktadır. Burada amaç diğerlerini ikna etmektir ve bilginin henüz yerleşmediği durumdan bilginin yerleştiği duruma doğru bir geçiş vardır (Hand ve diğerleri, 2017, 2018; Jang ve Hand, 2017). Öğrenciler araştırmaya test edilecek bir önerme (soru/öncül) ile başlamakta ve önerme belirleme işini bireysel, grup ve sınıfça olmak üzere üç farklı şekilde yapmaktadır. Sonrasında ise öğrenciler veri toplamakta ve kanıt üretmek için sonuç çıkarmaktadır. Bu aşamada öğrencilerin kanıtlarını oluşturmaları için verilerini gerekçelendirmeleri gerekmektedir. Öğrenciler, öncül ve kanıt (gerekçelendirme) arasında bir dizi gerekçelendirme belirlemekte ve nihai sonucu üretmektedir. Burada ifade edilen nihai sonuç, iddiadır. Walton üretilen iddiaların harici bir değerlendirilmesinin yapılması gerektiğinden bahsetmektedir. Bu bağlamda, grupça elde edilen iddia ve kanıtlar sınıfça tartışılmakta ve sonrasında disiplindeki bilgilerle iddiaların doğruluğu karşılaştırılmaktadır (Hand ve diğerleri, 2018). Bu süreç boyunca, öğrenciler argümantasyonu yazııı ve sözlü olarak gerçekleştirmekte ve okuma, yazma, konuşma, dinleme gibi dilin aktif olan dört bileşenini kullanmaktadır (Choi, Hand ve Greenbowe, 2013; Emig, 1977; Hand ve Keys, 1999).

"Özet yazma fazı" nda amaç bilgilendirme yapmaktır ve bu faz öğrenme amaçlı yazma etkinliklerini içermektedir. Bu fazda öğrencilerden büyük fikirlerini akranlarına ya da kendilerinden yaşça küçük birilerine anlatmaları beklenmektedir. Bu faz, özet yazma etkinliği başlığı altında anlatıldığı gibi, zihinsel olarak çaba gerektiren bir kısımdır. Öğrenciler bu aşamada, yazma etkinliklerinde kullanacağı materyali seçmekte, onları bir araya getirmekte ve birleştirmektedir. Ayrıca, öğrenciler fen dilini muhatabın anlayacağı dile çevirmekte ve büyük fikirleri açıklamak için hangi gösterimsel modları kullanacağını belirlemektedir (Hand ve diğerleri, 2017, 2018).

Tablo 1. Argümantasyon Tabanlı Öğrenme Yaklaşımının (ATBÖ) Üç Farklı Fazı

\begin{tabular}{|c|c|c|}
\hline $\begin{array}{l}\text { Epistemik çerçevenin altında } \\
\text { yatanların gelişimi }\end{array}$ & Argüman fazı (amaç ikna etmek) & $\begin{array}{l}\text { Özet yazma fazı (amaç } \\
\text { bilgilendirmek) }\end{array}$ \\
\hline \multirow{4}{*}{$\begin{array}{l}\text { Ünite "üç büyük fikir" etrafında } \\
\text { çerçevelendirilir } \\
\text { 1.Fen kavramı } \\
\text { 2.Öğrenme müzakere ile ilgilidir } \\
\text { 3.Dilin rolü }\end{array}$} & $\begin{array}{l}\text { Araştırmanın başlangıcı: } \\
\text { sorgulanacak öncül (bireysel/ } \\
\text { küçük grup/tüm sınıf müzakeresi) }\end{array}$ & $\begin{array}{l}\text { Büyük fikirlerin sentezinin } \\
\text { sergilenmesi: üç dönüşüm } \\
\text { beklenir }\end{array}$ \\
\hline & $\begin{array}{l}\text { *Sınıf tarafından üretilen (öncül ve } \\
\text { gerekçe) test edilecek soru (öncül) }\end{array}$ & $\begin{array}{l}\text { 1.Seçici: ilişkili olduğu düşünülen } \\
\text { materyali seçer }\end{array}$ \\
\hline & $\begin{array}{l}\text { *Sınıf tarafından üretilen (öncül ve } \\
\text { gerekçe) kullanılacak yöntem }\end{array}$ & $\begin{array}{l}\text { 2.Organizasyon: ilişkili materyalleri } \\
\text { belli bir düzende bir araya getirir }\end{array}$ \\
\hline & & $\begin{array}{l}\text { 3.Birleştirici: iki ya da daha fazla } \\
\text { önermeyi, fikri, olguyu ya da } \\
\text { iddiayı birleştirmek için bağlantılar } \\
\text { üretir. }\end{array}$ \\
\hline \multirow{4}{*}{$\begin{array}{l}\text { Öğrencilerin ön bilgileri } \\
\text { belirlenir ve ünite planı } \\
\text { öğrencilerin ön bilgileri dikkate } \\
\text { alınarak yapılır }\end{array}$} & \multirow{4}{*}{$\begin{array}{l}\text { Küçük grup müzakeresi sonucu } \\
\text { kanıt üretilir. Bu esnada, veri göz } \\
\text { önünde bulundurulur. } \\
\text { Inşa ve kritik ederek } \\
\text { gerekçelendirme sürecinin aktif } \\
\text { kullanımını gerektirir. }\end{array}$} & Konuların büyük fikirleri \\
\hline & & $\begin{array}{l}\text { Argüman fazı/sınıf aktivitelerindeki } \\
\text { bilgi iddialarını bağlantılar. }\end{array}$ \\
\hline & & $\begin{array}{l}\text { Akranına ya da daha genç bir } \\
\text { öğreniciye yazar }\end{array}$ \\
\hline & & Fen fikirlerini muhatabın diline \\
\hline
\end{tabular}




\begin{tabular}{|c|c|c|}
\hline & $\begin{array}{l}\text { Yöntemin uygulanmasından veri } \\
\text { elde edilir. } \\
\text { Kanıt üretmek için veri analiz edilir. } \\
\text { (veriler birbirine bağlantılanarak } \\
\text { gerekçelendirme aracılıyla bir dizi } \\
\text { önerme üretilir) }\end{array}$ & transfer eder. \\
\hline $\begin{array}{l}\text { Müzakere için kurallar geliştirilir } \\
\begin{array}{l}\text { 1. Insanlar değil fikirler } \\
\text { üzerinde durulur } \\
\text { 2. Grubun rolü önemlidir } \\
\text { Prosocial ortamın gelişimi } \\
\text {-bilgi uyanıklığı } \\
\text {-bilgi doğruluğu }\end{array}\end{array}$ & $\begin{array}{l}\text { İddia üretmek için harici } \\
\text { değerlendirme (inşa ve kritik } \\
\text { ederek gerekçelendirme sürecinin } \\
\text { aktif kullanımını gerektirir) } \\
\text { Seviye 1: küçük grup iddia ve } \\
\text { kanıtlarının tüm sınıfça } \\
\text { değerlendirmesi } \\
\text { Gerekçelendirmeyle savunulması } \\
\text { gerekir. } \\
\text { Seviye 2: disiplin normlarıyla } \\
\text { değerlendirilme } \\
\text { Grupça üretilen iddia ve kanıtların } \\
\text { disiplin normlarıyla } \\
\text { gerekçelendirilmesi }\end{array}$ & $\begin{array}{l}\text { Gösterimsel talepler } \\
\text { Kavramları açıklamak için uygun } \\
\text { modları kullanma } \\
\text { Metin ve diğer modlar arasındaki } \\
\text { uyum }\end{array}$ \\
\hline $\begin{array}{l}\text { Bilimsel epistemik } \\
\text { uygulamaların tartışılması } \\
\text {-soru üretilmesi } \\
\text {-araştırma yöntemi } \\
\text {-Soru/iddia/kanıt yapısı }\end{array}$ & $\begin{array}{l}\text { Sonuç: iddia (öncül ve } \\
\text { gerekçelendirme sonuca } \\
\text { yönlendiriyor) } \\
\text { *Tüm araştırma süreci boyunca bir } \\
\text { dizi gerekçelenmeye odaklanır- } \\
\text { toplam argüman } \\
\text { (soru+kanıt+iddia) } \\
\text { *ikna edici bir bilgi önermesi } \\
\text { üretilir. }\end{array}$ & $\begin{array}{l}\text { Kompleks bilgi etkinliği } \\
\text { Kritik analitik düşünme } \\
\text { Argüman bilgisi için farklı } \\
\text { epistemik etkinlik }\end{array}$ \\
\hline
\end{tabular}

Yukarıda verilen bilgilerden de anlaşılacağı gibi, ATBÖ yaklaşımı argümantasyon ve özet yazmaya (açıklamaya) dayalı iki öğrenme amaçlı yazma etkinliği içermektedir. Bu bağlamda Tablo 2 her iki yazma etkinliği arasındaki farkı açıklamaktadır. Öğrenciler, argümantasyona dayalı yazma etkinliklerinde kendilerini/öğretmenlerini ikna etmek için yazarken, özet yazma (açıklamaya dayalı yazma) etkinliklerinde ise öğretmenden farklı birilerine özellikle kendilerinden daha genç yaştaki bir muhataba bilgilendirme amaçlı yazmaktadır. Argümantasyona dayalı yazma etkinliklerinde henüz yerleşmemiş bilgiden bahsedilirken, özet yazma etkinliklerinde yerleşmiş bilgiden bahsedilmektedir. Argümantasyona dayalı yazma yapı olarak soru, iddia ve kanıt etrafında çerçevelenirken, özet yazma mektup, hikaye vb. tarzında yazma türlerini içermektedir (Jang ve Hand, 2017).

Tablo 2. Argümantasyon ve Özet Yazma Etkinliklerinin Karşılaştırılması

\begin{tabular}{lll}
\hline & Argümantasyona dayalı yazma & Özet Yazma (Açıklamaya dayalı yazma) \\
\hline Amaç & íkna etme & Bilgilendirme \\
Muhatap & Kendisi/öğretmen & Daha genç yaştaki öğrenciler \\
Bilginin doğası & Yerleşmemiş bilgi & Yerleşmiş bilgi \\
Tür & Yapı (soru, iddia, kanıt/karşılaştırma) & Sözel (mektup/hikaye)
\end{tabular}

illgili alanyazın incelendiğinde, argümantasyon tabanlı bilim öğrenme yaklaşımı ve geleneksel yöntemin karşılaştırıldı̆̆ı çalışmalarda, ATBÖ grubundaki öğrencilerin geleneksel öğretim yapan deney grubundaki öğrencilerden daha iyi kavramsal anlamaya sahip olduğu ortaya konulmuş (Günel ve diğerleri, 2010; Hand ve diğerleri, 2004, 2018; Hohensell ve Hand, 2006; Kıngır ve diğerleri, 2012; 2013; Mcdermott ve Hand, 2010) ve geleneksel olmayan öğrenme amaçlı yazma etkinliklerinin öğrencilerin öğrenmelerini ve kavramsal anlamalarını artırdığı rapor edilmiştir (Günel 
ve diğerleri, 2007; 2009; McDermott ve Hand, 2010). Ayrıca, geleneksel olmayan öğrenme amaçı̆ı yazma etkinliklerinin genellikle geleneksel olarak yapılan öğretimden sonra ünite bitiminde kullanıldığı ve bu yazma etkinlikleri üzerinde muhatabın etkisinin incelendiği görülmektedir (Hohenshell ve Hand, 2006; Jang ve Hand, 2017). Bu bağlamda, iki farklı amacı (ikna etmek ve bilgilendirmek) olan geleneksel olmayan yazma türleri verildiğinde öğrencilerin kavramsal anlamalarının nasıl değiștiğini inceleyen sınırlı sayıda çalışma bulunmaktadır. Yapılan çalışmalar incelendiğinde, öğrencilerin belirli bir bağlam içerisinde yer alan öğretici yazma etkinliklerine katılmaları sonucunda gerçekleşen öğrenmelerinin kalitesi üzerinde daha fazla deneysel çalışmalara intiyaç duyulduğu anlaşılmaktadır. Bu çalışmada, ilgili alandaki bu eksiklik giderilmeye çalışılacaktır. Bu bağlamda bu çalışmada öğrenme amaçlı yazma etkinliklerinden bir konuyu açıklamak amacıyla kullanılacak mektup türü ve amacı bir konuda başkalarını ikna etme amacıyla kullanılan argümantasyona dayalı yazma etkinliklerinin öğrencilerin kavramsal anlamaları üzerindeki etkisi incelenecektir.

\subsection{Amaç}

Bu çalışmanın amacı iki farklı yazma etkinliğinin -argümantasyon ve özet yazma (açıklama)öğrencilerin kavramsal anlamaları üzerindeki etkisini incelemektir. Aşağıda belirtilen araştırma soruları çalışmaya yön vermiştir:

1. Argümantasyon Tabanlı Bilim Öğrenme (ATBÖ) yaklaşımına ve geleneksel yönteme göre eğitim gören ortaokul 6. sınıf öğrencilerinin kavramsal anlamaları arasında istatistiksel olarak anlamlı bir fark var mıdır?

2. Argümantasyon Tabanlı Bilim Öğrenme (ATBÖ) yaklaşımına ve geleneksel yönteme göre eğitim gören ortaokul 6. sınıf öğrencilerinin özet yazma (açıklamaya dayalı yazma) etkinlikleri arasında istatistiksel olarak anlamlı bir fark var mıdır?

\section{YÖNTEM}

Bu çalışmada, deney ve kontrol gruplu, ön test- son test tasarımlı yarı deneysel yöntem kullanılmıştır. Bu bağlamda, deney grubunda ATBÖ yaklaşımına dayalı öğretim yapılırken, kontrol grubunda geleneksel yöntemle öğretim yapılmıştır.

\section{1 Çalışmanın Katılımcıları}

Çalışma, 2017-2018 eğitim öğretim yılında, İç Anadolu bölgesinde yer alan bir il merkezindeki bir ortaokulda dört farklı 6. sınıfta gerçekleştirilmiştir. Çalışmaya toplamda 84 öğrenci katılmıştır. Kontrol grubu olarak atanan iki sınıfta toplamda 43 (Sınıf 1=21, Sınıf 2=22) öğrenci, deney grubu olarak atanan iki sınıfta toplamda 41 (Sınıf 1=20, Sınıf 2=21) öğrenci bulunmaktadır. Çalışmaya katılan öğrencilerden deney grubunda 20 kIz, 21 erkek öğrenci bulunurken, kontrol grubunda 22 kız, 21 erkek öğrenci bulunmaktadır. Örneklem grubundaki öğrencilerin çoğunluğu sosyoekonomik olarak düşük ya da orta seviyeli ailelerin çocuklarından oluşmaktadır.

Çalışmadaki örneklem seçiminde amaçlı örneklemin tipik örneklem seçimi kullanılımıştır. Bu örneklem çeşidi, ilgilenilen olguyla ilgili ortalama bir durumu ya da olayı, kişiyi yansıtan bir örneklemdir (Merriam, 2009). Bu çalışmada, bu örneklem çeşidinin kullanılmasının sebebi, çalışılacak olan okulun tipik bir ortaokul ve burada öğrenim gören öğrencilerin ise tipik birer ortaokul öğrencileri olmalarıdır.

\subsection{Veri Toplama Araçları}

Çalışmada veri toplama aracı olarak, öğrencilerin ön bilgi ve başarı düzeylerini ölçmek için iki aşamalı kavram başarı testi ve özet yazma etkinliği rubriği kullanılmıştır.

\subsubsection{Kavram Başarı Testi}

Çalışmada, öğrencilerin anlama düzeylerini belirlemek amacıyla ortaokul 6. sınıf madde ve ısı ünitesine yönelik iki aşamalı kavram başarı testi geliştirilmiştir. İki aşamalı kavram başarı testinin ilk kısmı çoktan seçmeli olarak hazırlanmış, ikinci kısmında ise öğrencilerin çoktan seçmeli testte 
işaretlediği seçeneğin gerekçesini açıklaması istenmiştir. Illk kısmındaki çoktan seçmeli testin maddeleri hazırlanırken, tanılayıcı dallanmış ağaç, yapılandırımış grid ve kavram karikatürleri kullanılmıştır. Aşağıda bu sorular ile ilgili birer örnek sunulmuştur (Şekil 1, 2, ve 3). Ayrıca, kavram başarı testinin maddeleri fen bilgisi alanında uzman üç öğretim üyesi ve iki fen bilgisi öğretmeni tarafından incelenmiş ve soruların kapsam geçerliliğine sahip olup olmadığına karar verilmiştir. 90 öğrenciyle pilot çalıșma yapılmıştır. Testin pilot çalışmasının Cronbach alfa sonucu 0.84 olarak bulunmuştur. Yapılan geçerlik ve güvenirlik analizinden sonra bazı maddelerde düzeltme yapılmış ve testin son halinde toplamda 20 soru yer almıştır.

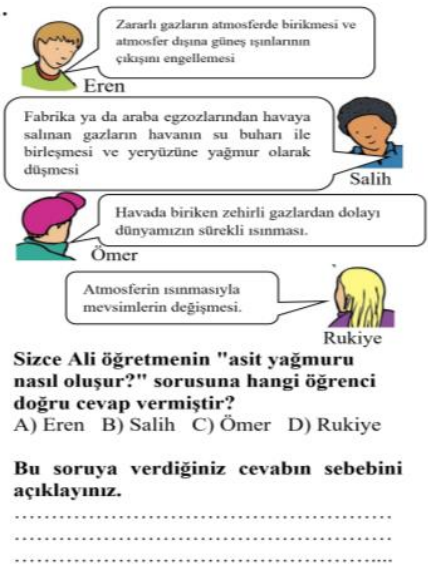

Şekil 1. Kavram Karikatürü Soru Örneği

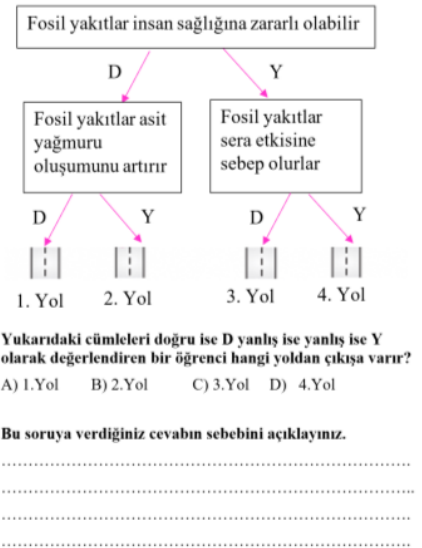

Şekil 2. Tanılayıcı Dallanmış Ağaç Soru Örneği

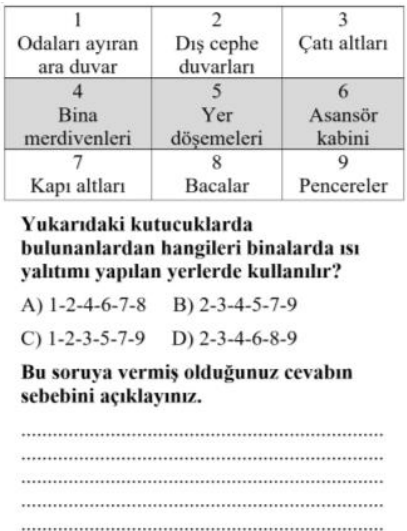

Şekil 3. Yapılandırıımış Grid Soru Örneği

\subsection{1 Özet Yazma Etkinliği Rubriği}

Çalışmada kullanılan diğer veri toplama aracı özet yazma etkinliği rubriğidir. Bu rubrik, çalışma kapsamında dörtlü likert tipli (kötü, orta, iyi ve çok iyi) olarak geliștirilmiştir. Rubrikteki kriterler geliştirilirken ilgili alan yazın taraması yapılmış ve uzman görüşleri alındıktan sonra rubriğe son hali verilmiştir. Tablo 3'te görüldüğü gibi rubrikteki kriterlerde, öğrencilerin konuları ve bilimsel içeriği açık bir şekilde ifade edip etmediği, 6. Sınıftaki öğrencilerin 4. sınıftaki muhataplarının seviyesine uygun yazıp yazmadığı, öğrencilerin yazdıkları mektupta resim, şekil vb. gibi çoklu gösterimleri kullanıp kullanmadığı, konunun gidişatının anlaşıır olup olmadığı, kullanılan cümlelerin akıcı olup olmadığı ve öğrencilerin verdikleri örneklerin anlaşıır olup olmadığı ölçülmeye çalışılmıştır.

Tablo 3. Öğrenme Amaçlı Yazma Etkinliklerini Değerlendirme Rubriği

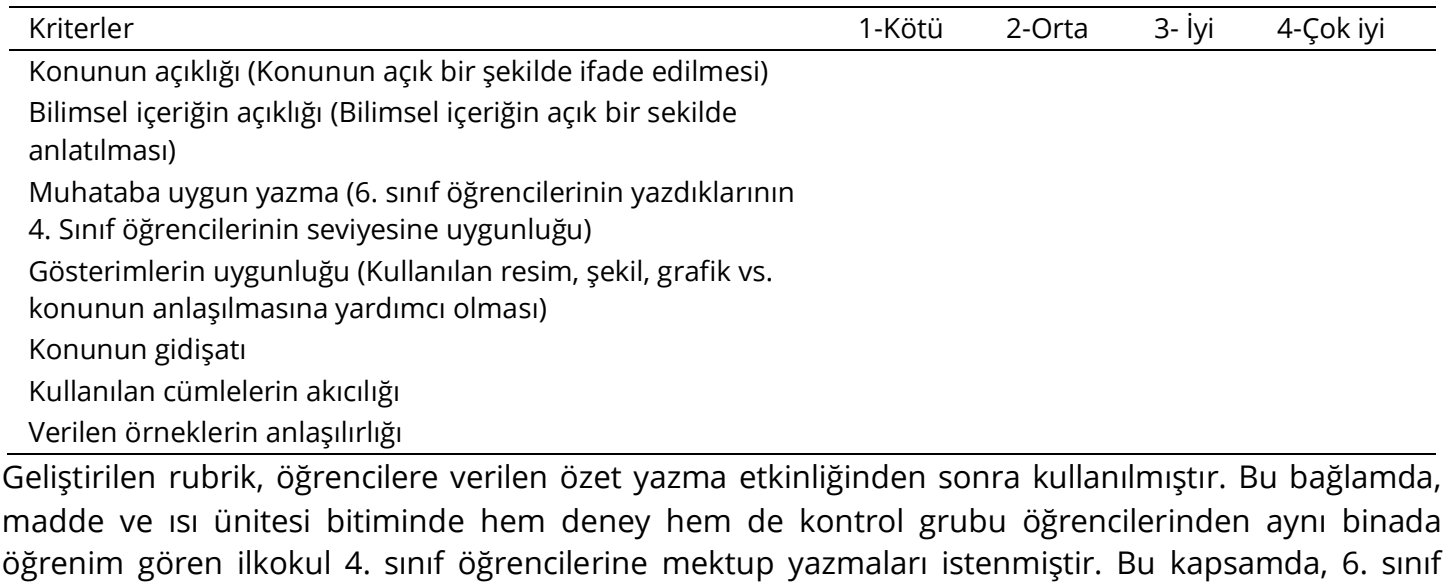


öğrencilerine 4. sınıflardan gelen Şekil 4'te gösterilen mektup okunmuştur ve 6. sınıf öğrencilerinden 4. sınıf öğrencilerinin sorduğu sorulara cevap olacak mektupları yazmaları istenmiştir. Bu bağlamda, 6. sınıftaki öğrenciler 4. sınıftaki öğrencileri muhatap alarak mektuplarını yazmıştır. Çalışma kapsamında, muhatap olarak 5. sınıf ya da 3. sınıf öğrencileri de alınabilirdi, ancak 4. sınıftaki öğrencilerin yazdıkları mektuba binaen 4. sınıftaki öğrenciler muhatap olarak alınmıştır. Burada önemli olan öğrencilerin akranlarına ya da kendilerinden yaşça küçük birilerine yazmasıdır. Özet yazma etkinliği, yazma etkinlikleri konusunda fen bilgisi eğitimi alanında uzman bir öğretim üyesi tarafından incelenmiştir.

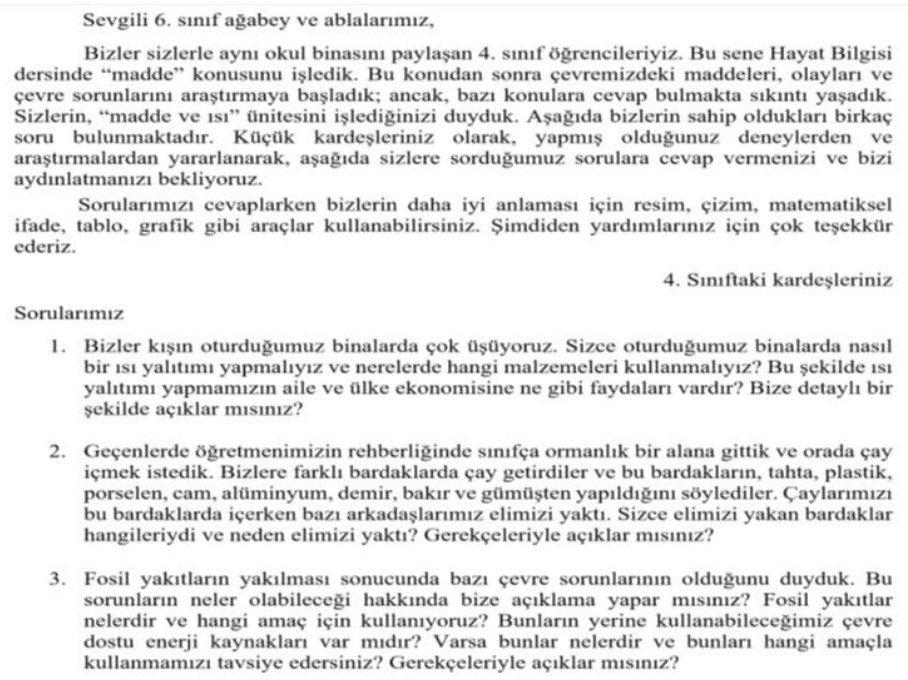

Şekil 4. Mektup Örneği

\subsection{Verilerin Analizi}

\subsubsection{Kavram Başarı Testi Analizi}

iki aşamalı teşhis testinin madde analizi sürecinde kullanılan puanlama anahtarı çoktan seçmeli ve açık uçlu kısımlarına verilen puanların toplanmasından oluşmuştur. Bu bağlamda, öğrenciler iki aşamalı teşhis testinin çoktan seçmeli kısmına verdiği cevaplar doğruysa 1, yanlışsa 0 puan almıştır. Testin ikinci aşaması olan gerekçe kısımları ise doğru anlama, kısmen doğru anlama, kavram yanılgıı anlama, yanlış anlama ve boş olmak üzere 5 kısma ayrılmıştır (Yaman ve Ayas, 2015). Öğrencilerin verdikleri doğru cevaba 4, kısmen doğru cevaba 3, kavram yanılgılı cevaba 2, yanlış cevaba 1 ve boş kısma 0 puan verilmiştir. Bu kısımda öğrencilerin yanlış cevaplarına da puan vermek onları yazmaları konusunda cesaretlendirmek içindir. Öğrencilerin her iki kısımda aldıkları puanlar toplam puanları olmuştur. Bu bağlamda, bir öğrenci bir sorudan en fazla 5 puan alabilmektedir. Örneğin, öğrenci soruya doğru cevap (1 puan)-doğru gerekçe (4 puan) verdiğinde 5 puan, doğru cevap (1 puan) kısmen doğru (3 puan) cevap verdiğinde 4, yanlış cevap (0 puan)kısmen doğru cevap (3 puan) verdiğinde 3 puan almaktadır. Tablo 4'te testin ikinci aşamasında verilen cevapların anlama seviyelerine göre kategorilendirilmesi, puanlamada kullanılan kriterler ve öğrenci cevapları yer almaktadır. Bu bağlamda, deney ve kontrol grubundaki bazı öğrencilerin son testte Şekil 1, 2 ve 3'te yer alan sorulara verdiği cevaplar Tablo 4'te sergilenmiştir. 
Tablo 4. Kavram Başarı Testinin İkinci Kısmı için Kullanılan Anlama Seviyeleri, Puanlamada Kullanılan Kriterler ve Öğrenci Cevapları

\begin{tabular}{|c|c|c|c|c|}
\hline \multirow{2}{*}{$\begin{array}{l}\text { Anlama } \\
\text { seviyeleri }\end{array}$} & \multirow{2}{*}{$\begin{array}{l}\text { Puanlamada } \\
\text { kullanılan kriterler }\end{array}$} & \multicolumn{3}{|c|}{ Şekil 1, 2 ve 3'te yer alan sorular için örnek öğrenci cevapları } \\
\hline & & $\begin{array}{l}\text { Şekil 1'de yer alan } \\
\text { soru }\end{array}$ & Şekil 2'de yer alan soru & $\begin{array}{l}\text { Şekil 3'de yer alan } \\
\text { soru }\end{array}$ \\
\hline $\begin{array}{l}\text { Doğru } \\
\text { anlama }\end{array}$ & $\begin{array}{l}\text { Geçerli cevabın } \\
\text { bütün bileşenlerini } \\
\text { içeren cevaplar }\end{array}$ & $\begin{array}{l}\text { Çünkü araba } \\
\text { egzozları ve } \\
\text { fabrikalardan } \\
\text { havaya salınan } \\
\text { gazlar havanın } \\
\text { subuharı ile } \\
\text { birleşince yeryüzüne } \\
\text { asit yağmuru olarak } \\
\text { düşer }\end{array}$ & $\begin{array}{l}\text { Fosil yakıtlar insan } \\
\text { sağlığına zararlı olabilir ve } \\
\text { bu gazlar fabrikalardan vs } \\
\text { havaya bırakılınca } \\
\text { havadaki subuharı ile } \\
\text { birleşir ve asit yağmuru } \\
\text { oluşur. Bu yüzden fosil } \\
\text { yakıtların kullanımı asit } \\
\text { yağmuru oluşumunu } \\
\text { artırır }\end{array}$ & $\begin{array}{l}\text { Çünkü odaları } \\
\text { ayıran duvar, dış } \\
\text { cephe duvarları, } \\
\text { çatı ve kapı altları, } \\
\text { yer döşemeleri ve } \\
\text { penceler } \\
\text { binalarda ısı } \\
\text { akışının en fazla } \\
\text { olduğu yerlerdir }\end{array}$ \\
\hline $\begin{array}{l}\text { Kısmen } \\
\text { doğru } \\
\text { anlama }\end{array}$ & $\begin{array}{l}\text { Geçerli cevabın } \\
\text { hepsini değil en az } \\
\text { bir bileşenini } \\
\text { içeren cevaplar }\end{array}$ & $\begin{array}{l}\text { Çünkü gazlar } \\
\text { havada subuharı ile } \\
\text { birleşiyor ve asit } \\
\text { yağmuru olarak } \\
\text { iniyor }\end{array}$ & $\begin{array}{l}\text { Çünkü fosil yakıtlar } \\
\text { artıkça insanların zararına } \\
\text { olabiliyor bunun } \\
\text { sonucunda asit } \\
\text { yağmurları artıyor }\end{array}$ & $\begin{array}{l}\text { Çünkü bina } \\
\text { merdivenlerine ısı } \\
\text { yalıtımına gerek } \\
\text { yoktur }\end{array}$ \\
\hline $\begin{array}{l}\text { Kavram } \\
\text { yanılgılı } \\
\text { anlama }\end{array}$ & $\begin{array}{l}\text { Bilimsel olarak } \\
\text { kabul edilenden } \\
\text { farklı, değişime } \\
\text { dirençli, yapılan } \\
\text { öğretimden sonra } \\
\text { bile varlığını } \\
\text { sürdüren cevaplar }\end{array}$ & $\begin{array}{l}\text { Çünkü asit } \\
\text { yağmurları havada } \\
\text { biriken zehirli } \\
\text { gazlardan oluşur }\end{array}$ & $\begin{array}{l}\text { Bu kategoride, bu soru } \\
\text { için öğrenci cevabı } \\
\text { bulunmamaktadır }\end{array}$ & $\begin{array}{l}\text { Bu kategoride, bu } \\
\text { soru için öğrenci } \\
\text { cevabı } \\
\text { bulunmamaktadır }\end{array}$ \\
\hline $\begin{array}{l}\text { Yanlış } \\
\text { anlama }\end{array}$ & $\begin{array}{l}\text { Doğru olmayan, } \\
\text { mantıksız, ilgisiz ya } \\
\text { da açık olmayan } \\
\text { cevaplar }\end{array}$ & $\begin{array}{l}\text { Çünkü güneş çıkışı } \\
\text { engellenir atmosfer } \\
\text { dışına güneş } \\
\text { geçemez }\end{array}$ & $\begin{array}{l}\text { Çünkü fosil yakıtlar sera } \\
\text { etkisine sebep olmaz }\end{array}$ & $\begin{array}{l}\text { Yalıtım } \\
\text { malzemeleri } \\
\text { aralara döşenir } \\
\text { ama binalarda } \\
\text { oralara }\end{array}$ \\
\hline Boş & $\begin{array}{l}\text { Boş bırakılan ya da } \\
\text { bilmiyorum } \\
\text { şeklinde verilen } \\
\text { cevaplar }\end{array}$ & Bilmiyorum & Boş bırakılmış & Boş bırakılmış \\
\hline
\end{tabular}

Öğrencilerin kavram başarı testine verilen cevapları yukarıda bahsedilen şekilde puanlandırıldıktan sonra ön testten ve son testten aldıkları puanlar SPSS-21 paket programı kullanılarak analiz edilmiştir. Bu bağlamda, öncelikle deney ve kontrol gruplarının ön test ve son test puanları bakımından normal dağılıma sahip olup olmadığı belirlenmiştir. Gruplardaki öğrenci sayıları 50'nin altında olduğu için SPSS programında Shapiro Wilk ile çarpıklık ve basıklık katsayıları hesaplanmıştır. Shapiro Wilk sonuçlarının p>.05, çarpıklık ve basıkıı katsayılarının ise -1 ve +1 değerleri arasında yer alma durumunda verilerin normal dağıldığı kabul edilmiştir (Büyüköztürk, 2018). Ön test ve son test puanları bakımından deney ve kontrol grupları normal dağılım göstermediği için ön test ve son test ortalama puanlarını karşılaştırmak amacıyla parametrik olmayan testlerden Kruskal Wallis kullanılmıştır.

\subsection{2 Özet Yazma Etkinliği Rubriği Analizi}

Her iki grupta yer alan öğrencilerin hazırladıkları 84 adet mektup yazma etkinliği çalışma için geliştirilen rubrikle değerlendirilmiştir. Bunun için öncelikle herbir öğrencinin yazdığı özet yazma etkinliği baştan sonra okunmuş ve rubrikte yer alan kriterler gözönünde bulundurularak gerekli puanlar verilmiştir. Bu bağlamda, kötü için 1, orta için 2, iyi için 3 ve çok iyi için 4 puan verilmiştir. Rubrikte yedi kriter bulunmaktadır. Bir öğrencinin alabileceği maksimum puan 28'dir. Öğrencilerin 
özet yazma etkinliğinin puanlamasının güvenirliği için iki farklı araştırmacı rasgele seçilen 10 mektup yazma etkinliğini birbirinden bağımsız olarak puanlamış ve puanlamalar arasında \% 86 uyum bulunmuştur. Öğrencilerin mektupları puanlandıktan sonra elde edilen veriler SPSS analizine tabi tutulmuştur. Bu bağlamda, kontrol ve deney gruplarının özet yazma etkinlikleri puanları bakımından normal dağılıma sahip olup olmadığı belirlenmiştir. Shapiro Wilk sonuçları doğrultusunda, özet yazma etkinlikleri puanları bakımından deney ve kontrol grupları normal dağılım göstermediği için, ortalama puanları karşılaştırmak amacıyla parametrik olmayan testlerden Kruskal Wallis testi kullanılmıştır.

\subsection{Süreç}

Çalışma hem deney hem de kontrol grubunda beş haftalık bir zaman diliminde haftada dört ders saatini (4*40 dakika) kapsayacak şekilde uygulanmıştır. Çalışmanın yürütülebilmesi için MEB'den gerekli izinler alınmıştır. Ortaokulda yer alan dört 6. sınıftan ikisi rastgele deney ve diğer ikisi de kontrol grubu olarak atanmıştır. Her iki gruptaki öğretim, öğrencilere kavram başarı testi ön test olarak verildikten bir hafta sonra başlamıştır. Aynı test, çalışma bittikten bir hafta sonra her iki gruba son test olarak uygulanmıştır. Özet yazma etkinlikleri ise son testten sonra uygulanmıştır. Öğrenciler, özet yazma etkinlikleri kapsamında 4. sınıf öğrencilerine mektup yazmıştır. Tablo 5 deney ve kontrol grubuna yapılan etkinlikleri ve kullanılan veri toplama araçlarının haftalara göre dağılımını göstermektedir.

Tablo 5. Deney ve Kontrol Grubundaki Öğrencilerin Yaptıkları Etkinliklerin Haftalara Göre Dağılımı

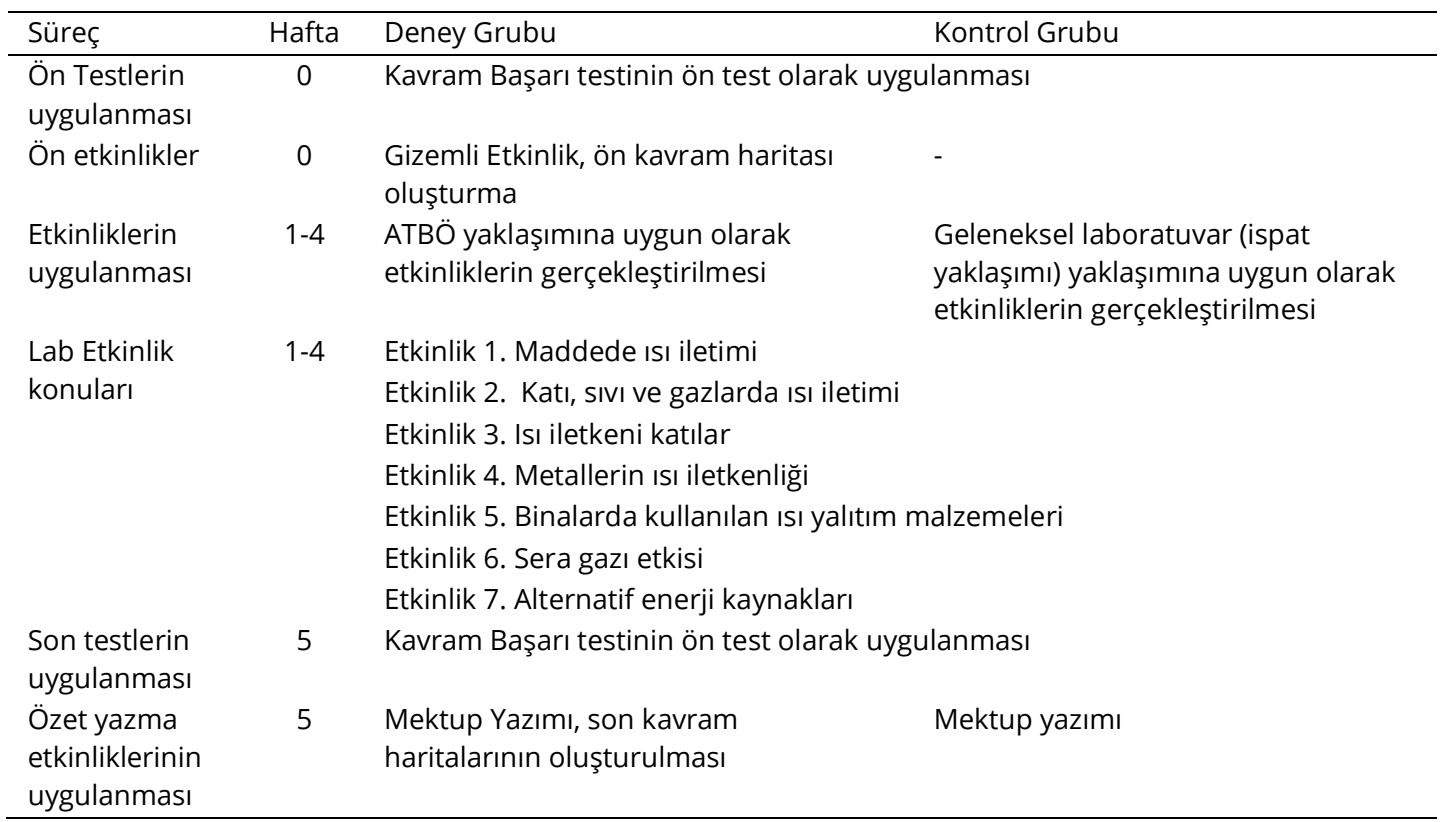

Deney ve kontrol grubundaki etkinlikler sekiz yıllık öğretmenlik deneyimi olan bir fen bilgisi öğretmeni tarafından yürütülmüştür. Diğer bir ifadeyle, tek bir fen bilgisi öğretmeninin dört sınıfı, rastgele deney ve kontrol grubu olarak atanmış ve etkinlikler aynı öğretmen tarafından yürütülmüştür. Her iki gruba uygulamayı yapan fen bilgisi öğretmeni, uygulama öncesinde geleneksel laboratuvar yaklaşımıyla ilgili bilgiye ve deneyime sahipken, ATBÖ yaklaşımı ile ilgili herhangi bir bilgiye ve deneyime sahip olmadığı için uygulama öncesinde ATBÖ yaklaşımı ile ilgili eğitim almış ve fen bilgisiyle ilgili başka konularda uygulamalar yapmıştır. Her grupta etkinlikler beş haftalık bir zaman diliminde yapılmıştır ve etkinliklere eşit süreler ayrılmıştır. Bir araştırmacı, öğretmen etkisini kontrol altında tutmak için hem deney hem de kontrol grubundaki dersleri takip etmiş ve notlar tutmuştur. Yapılan gözlemler sonucunda öğretmenin her bir gruptaki uygulamaları için deney ve kontrol gruplarında yapılan öğretimin doğasına uygun olarak öğretim yaptığı belirlenmiştir. Deney ve kontrol grubundaki öğrenciler "maddede Isı iletimi, katı, sıvı ve gazlarda ısı 
iletimi, Isı iletkeni katılar, metalletin ısı iletkenliği, binalarda kullanılan ısı yalıım malzemeleri, sera gazı etkisi ve alternatif enerji kaynakları" konularında toplamda yedi adet etkinlik yapmıştır. Deney grubundaki öğrenciler, yedi etkinliği ATBÖ yaklaşımına uygun olarak gerçekleştirmiş ve Tablo 6'da görüldüğü gibi bu yöntemin öğrenci şablonunu kullanmıştır. Kontrol grubundaki öğrenciler ise geleneksel laboratuvar yaklaşımına (ispat yaklaşımı) uygun olarak etkinliklerini gerçekleştirmiş ve geleneksel laboratuvar rapor formatını kullanmıştır (bakınız Tablo 6). Bu bağlamda, deney grubundaki öğrenciler yedi etkinliği argümantasyona dayalı yazma etkinliklerini kullanarak raporlaştırırken, kontrol grubundaki öğrenciler yedi etkinliği geleneksel yazma etkinliklerini kullanarak raporlaştırmıştır. Tablo 6, deney ve kontrol grubundaki öğrencilerin kullandıkları rapor formatlarını ve onlardan bu süreçte istenenleri açıklamaktadır (Burke, Greenbowe ve Hand, 2005).

Tablo 6. Geleneksel Laboratuvar formatı ve ATBÖ Öğrenci Şablonu ve Öğrencilerden İstenenler

\begin{tabular}{|c|c|c|c|c|}
\hline $\begin{array}{l}\text { Laboratuvar } \\
\text { etkinliklerinin } \\
\text { zaman } \\
\text { çizelgesi }\end{array}$ & $\begin{array}{l}\text { Geleneksel } \\
\text { Lab Öğrenci } \\
\text { formatı }\end{array}$ & $\begin{array}{l}\text { Öğrenciden } \\
\text { istenenler }\end{array}$ & $\begin{array}{l}\text { ATBÖ Öğrenci } \\
\text { Şablonu }\end{array}$ & Öğrenciden istenenler \\
\hline $\begin{array}{l}\text { Laboratuvar } \\
\text { Öncesi }\end{array}$ & $\begin{array}{l}\text { Laboratuvar } \\
\text { öncesi } \\
\text { sorular }\end{array}$ & $\begin{array}{l}\text { Lab föyündeki } \\
\text { deney öncesi } \\
\text { sorulara çalışıp gelir }\end{array}$ & $\begin{array}{l}\text { 1.Başlangıç } \\
\text { soruları } \\
\text { (bireysel) } \\
\text { 2.Yöntem } \\
\text { (bireysel) }\end{array}$ & $\begin{array}{l}\text { a) Öğrenciler bireysel başlangıç } \\
\text { soruları hazırlar b) başlangıç } \\
\text { sorularına cevap bulabilmek için } \\
\text { yöntem araştırır c) yöntem için } \\
\text { alınması gereken önlemleri } \\
\text { belirler d) Ön kavram haritası } \\
\text { hazırlar }\end{array}$ \\
\hline \multirow[t]{3}{*}{$\begin{array}{l}\text { Laboratuvar } \\
\text { Esnası }\end{array}$} & $\begin{array}{l}\text { 1.Başlık ve } \\
\text { amaç } \\
\text { 2. Deneyin } \\
\text { yapılışı }\end{array}$ & $\begin{array}{l}\text { a) Öğretmen adım } \\
\text { adım talimatlar } \\
\text { verir b) Öğrenciler } \\
\text { lab föyünde yazılı } \\
\text { olan deneyin } \\
\text { yapılışı kısmını } \\
\text { basamak basamak } \\
\text { uygular }\end{array}$ & $\begin{array}{l}\text { 1.Başlangıç } \\
\text { soruları (grup) } \\
\text { 2.Yöntem } \\
\text { (grup) }\end{array}$ & $\begin{array}{l}\text { a) Öğrenciler tahtaya araştırmak } \\
\text { istedikleri soruları yazar b) Sınıf } \\
\text { hep birlikte hangi soruların } \\
\text { inceleceğini tartışır c) Öğrenciler, } \\
\text { sorularını test edebilmek için } \\
\text { nasıl bir yol izleyeceklerine karar } \\
\text { verirler. }\end{array}$ \\
\hline & $\begin{array}{l}\text { 3. Veri ve } \\
\text { Gözlemler }\end{array}$ & $\begin{array}{l}\text { a) Öğrenciler } \\
\text { bireysel ya da grup } \\
\text { arkadaşlarıyla } \\
\text { deneyi yapar b) } \\
\text { Öğrenciler grup } \\
\text { arkadaşlarıyla } \\
\text { konuşur ancak } \\
\text { diyologların sayısı } \\
\text { azdır ve öğretmen } \\
\text { merkezlidir. }\end{array}$ & $\begin{array}{l}\text { 3.Gözlemler- } \\
\text { Ne gördüm? }\end{array}$ & $\begin{array}{l}\text { a) Öğrenciler, veri toplamak ve } \\
\text { deney yapmak için gruplara } \\
\text { ayrılırlar b) bağımlı ve bağımsız } \\
\text { değişkenleri içeren grup ve sınıf } \\
\text { tablosu hazırlar c) Verileri analiz } \\
\text { etmek için örüntü ve } \\
\text { anormalliklere bakar d) verilerde } \\
\text { anormallik varsa deneyi tekrar } \\
\text { uygular e) grafikler oluşturur ve } \\
\text { sonuçları yorumlar }\end{array}$ \\
\hline & $\begin{array}{l}\text { 4.Tartışma } \\
\text { 5. Sonuç }\end{array}$ & $\begin{array}{l}\text { Öğrenci, grup } \\
\text { arkadaşına ya da } \\
\text { öğretmenine bir } \\
\text { soru sorabilir ve } \\
\text { sonra sınıftan } \\
\text { ayrılabilir. }\end{array}$ & $\begin{array}{l}\text { 4.iddialar- } \mathrm{Ne} \\
\text { iddia } \\
\text { edebilirim? } \\
\text { 5.Kanıt-Nasıl } \\
\text { bilebilirim? } \\
\text { Neden bu tür } \\
\text { iddalarda } \\
\text { bulunuyorum? }\end{array}$ & $\begin{array}{l}\text { a) Grup içerisindeki her öğrenci } \\
\text { verilere ve gözlemlere dayalı } \\
\text { olarak iddia ve kanıtlar oluşturur } \\
\text { b) Grup olarak öğrenciler kendi } \\
\text { iddia ve kanıtlarını paylaşırlar ve } \\
\text { sonunda grup iddia ve kanıtlarını } \\
\text { oluştururlar c) Her bir grup } \\
\text { sırasıyla diğer gruplara } \\
\text { araştırdıkları soruyu, ne } \\
\text { yaptıklarını ve araştırma } \\
\text { sonucunda ne iddia ettiklerini } \\
\text { anlatır. Her bir grup iddialarını } \\
\text { kanıtlarla destekler }\end{array}$ \\
\hline
\end{tabular}




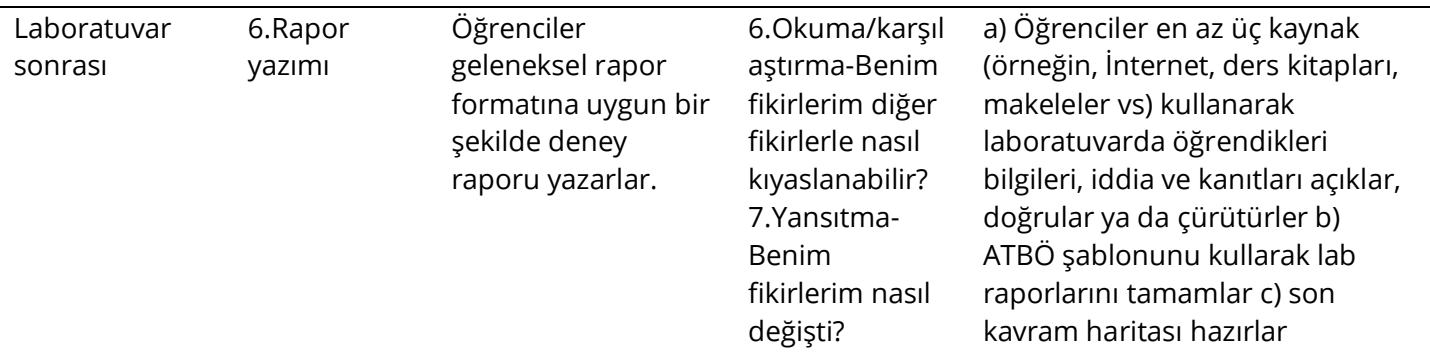

\subsubsection{Deney Grubunda ATBÖ Yaklaşımının Uygulanma Süreci}

Deney grubunda etkinlikler ATBÖ yaklaşımına uygun olarak yapılmış ve Tablo 6'da görüldüğü gibi bu yöntemin "başlangıç soruları, yöntem, gözlem, iddia, kanıt, okuma ve yansıtma" bölümlerinden oluşan öğrenci şablonu kullanılmıştır (Hand ve diğerleri, 2004; Kıngır ve diğerleri, 2013; NortonMeier ve diğerleri, 2008). Çalışma başlamadan önce ATBÖ yaklaşımının uygulandı̆̆ı deney gruplarında öğrencilerden 4-5 kişilik gruplar oluşturmaları istenmiştir. Sonrasında ise fen ile alakası olmayan bir konuda "gizemli etkinlik" adı verilen bir etkinlik yaptırılarak öğrenciler ATBÖ yaklaşımı ile tanıştırılmıştır (Burke, Greenbowe ve Hand, 2005). Bu etkinlikteki amaç, soru iddia ve kanıt üçlüsünden oluşan argüman oluşturma sürecinin öğrenciler tarafından doğru anlaşıımasını sağlamaktır.

Yapılan gizemli etkinlikten sonra öğretmen, yeni başlayacakları ünitede yer alan kavramlarla ilgili öğrencilerle birlikte, onların ön bilgilerini ölçmek amacıyla bir sınıf kavram haritası oluşturmuştur. Bu bağlamda, ısı iletimi, ISı yalııımı, ISı yalıtkanı, ISı yalıtım malzemeleri, yakıtlar, alternatif enerji kaynakları ile ilgili kavramlar kullanılmıştır. Sonrasında ise, öğrencilerden bu ünite kapsamında araştırmak istedikleri soruları belirlemeleri istenmiştir. (Laboratuvar öncesi bireysel başlangıç sorularının belirlenmesi). Öğrencilerle birlikte kavram haritası oluşturulduktan sonra, bir sonraki haftanın konusu olan maddenin ISı iletimi konusunda neleri araştırmak istedikleri sorulmuştur. Öğrencilerden gruplar halinde araştırmak istedikleri soruları belirlemeleri ve sınıf tahtasına yazmaları istenmiştir. Öğretmen bu esnada sınıfta dolaşarak grupların sorularını, araştırma sorusundaki bağımlı bağımsız değişkenleri, bu soruları araştırmak için hangi yöntemleri kullanacaklarını sormuştur (Laboratuvar esnası-grup başlangıç soruları ve yöntemin belirlenmesi). Yapılan sınıf tartışmasından sonra sınıf başlangıç soruları olarak "Maddeler ısıyı nasıl iletir? Her metalin ıSı iletkenliği aynı mıdır? Metalin türünün ISı iletkenliğine etkisi nasıldır?" soruları belirlenmiştir (Laboratuvar esnası-sınıf başlangıç sorularının belirlenmesi).

Öğrenciler belirledikleri sorulara cevap bulabilmek için nasıl bir etkinlik tasarlayacağını tartışmıştır. Bu bağlamda, gruplardan bir tanesi kendi gruplarının yöntemini "uzun bir metal şerit alırız. Mumları eşit büyüklükte keseriz ve eşit uzaklıklara yerleştiririz. İspirto ocağını metalin ucuna yerleştiririz ve mumların yere düşme sürelerini kaydederiz" şeklinde belirtirken, diğer bir grup "aynı uzunluktaki farklı metal şeritleri (demir, gümüş, alüminyum ve bakır gibi) alırız, aynı büyüklükte mumlar keseriz ve metallerin üzerine yerleştiririz. Bu metallerin hepsini aynı ispirto ocağına tutarız ve mumların düşme sürelerini kaydederiz" şeklinde ifade etmiştir. Başka bir grup ise "farklı metallerin (demir, gümüș, alüminyum ve bakır gibi) bir noktada birleştiği metal malzemeyi alırız ve üzerine eşit büyüklükte mumlar yerleştiririz ve ispirto ocağını metallerin birleşme noktasına tutarız ve mumların düşme sürelerini kaydederiz" şeklinde ifade etmiştir (Laboratuvar esnası-yöntemlerin belirlenmesi).

Grupların hepsi izleyeceği yolu belirledikten sonra başlangıç sorularına cevap bulabilmek için grup içerisinde görev dağılımı yapılmıştır. Öğretmen ise bu esnada, laboratuvar içerisinde gruplar arasında dolaşarak onlara çeşitli sorular sormuştur (örneğin, bu etkinlikteki kontrol ettiğiniz değişkenleriniz nelerdir? Etkinlikte neler gözlemlediniz? Elde ettiğiniz sonuçları tablo, grafik ya da şekil olarak ifade edebilir misiniz? Verilerinizi nasıl yorumlarsınız? Verileriniz arasında herhangi bir ilişki var mı?). Bu esnada öğrencilerin sordukları sorulara direk cevap vermemiş onları grup arkadaşlarına ya da diğer gruplara yönlendirmiştir. Deneylerini bitirdikten sonra bütün gruplar elde 
ettiği verileri tahtaya yazmıştır. Bu bağlamda, öğrencilerle birlikte sınıf tahtasında her grubun verilerini girebilmelerini sağlayacak bir tablo oluşturulmuştur (Laboratuvar esnası- gözlemler).

Öğretmen tahtadaki verilerden nasıl bir örüntü çıkarabileceklerini öğrencilere sormuştur. Sonrasında her bir grup verileri ve başlangıç sorularını dikkate alarak iddialarını ve bu iddialarına temel teşkil edecek kanıtlarını önce grup içerisinde tartışıp bir karara bağlamış sonrasında ise iddia ve kanıtlarını diğer gruplara sunmuştur. Bu bağlamda, gruplardan bir tanesi sınıf tartışması esnasında iddiasını "ısı bir taneciğin diğer bir taneciğe çarpışması sonucu iletilir ve her maddenin ısı iletkenliği maddenin türüne göre değişir" şeklinde belirtmiştir. İddialarını kanıtlamak için elde ettikleri verileri gerekçelendirmiştir. Bu bağlamda, kanıtlarını "ISı bir taneciğin diğerine çarpması sonucu iletilir çünkü ISı maddelerin hareketini artııır ve maddelerin taneciklerinin hareketi arttı̆ için daha hızı titreşir. Titreşen tanecikler çizdiğimiz şekillerde görüldüğg̈ gibi yanındaki taneciğe çarparak enerjilerinin bir kısmını onlara iletirler, böylelikle ısı metalin bir ucundan diğer bir ucuna iletilmiş olur" şeklinde ifade etmiş̧ir (Laboratuvar esnası-iddia ve kanıtların belirlenmesi).

Öğrenciler, iddialarını savunurken iki şekil çizmiştir. Çizdikleri birinci şekilde deneyde kullandıkları metal çubuğu çizip metalin taneciklerini yuvarlak şeklinde çizerek göstermiştir ve metalin üzerine eşit aralıklarla beş mum çizmiştir. İkinci şekilde, ispirto ocağına yakın olan mumun daha önce eridiğini, diğerlerinin de sırasıyla eridiğini göstermiştir. Aynı grup "her maddenin ısı iletkenliği maddenin türüne göre değişir" iddialarını kanıtlamak için "ISı iletkenliği maddenin türüne göre değişir çünkü kullandığımız gümüş, bakır, alüminyum ve demirin üzerindeki mumlar farklı zamanlarda erimiştir. Bunlar farklı metal olduğu için ve her birinin üzerindeki mum farklı zamanlarda eridiği için maddenin türü ısı iletkenliğini etkiler. Yaptığımı deneyde metallerin üzerindeki mumların erime sıralaması gümüş> alüminyum > bakır >demir"dir şeklinde savunma yapmıştır. Başka bir grup ise, bu sıramaya ulaşamadıklarını onların sıralamasının gümüş>bakır> demir> alüminyum şeklinde olduğunu ifade etmiştir (Laboratuvar esnası-iddia ve kanıtların belirlenmesi).

Öğretmen bu esnada, tüm sınıfa grupların farklı sıralama bulmalarının sebeplerini sormuştur. Yapılan sınıf tartışması esnasında grupların birindeki öğrencilerin kullandıkları mum miktarlarının birbirinden farklı olduğu, alüminyum metali için kullanılan mum miktarının demir için kullanılandan daha fazla miktarda olduğu, diğer bir grubun farklı metal şeridi ayrı ayrı kullandıkları için bunları ispirto ocağına eşit uzaklıkta tutamadıkları ortaya çıkmış ve bu durumun sonuçlarını yanlış bir şekilde etkileyebileceği sonucuna varılmıştır. Bu bağlamda, sınıfça yapılan tartışmadan sonra metallerin sıralamasının gümüş>bakır>alüminyum>demir şeklinde olması gerektiğine karar verilmiştir. Bütün gruplar iddia ve kanıtlarını sunup sınıf tartışması yapıldıktan sonra öğrencilerin herhangi bir konuda anlaşmazlığı olup olmadığı sorulmuştur (Laboratuvar esnası-iddia ve kanıtların belirlenmesi). Sonrasında ise öğrencilerden en az üç farklı kaynaktan araştırma yapmaları ve iddia ve kanıtlarını desteklemeleri ya da çürütmeleri istenmiştir (Jang ve Hand, 2017; Kıngır ve diğerleri, 2013; Norton-Meier ve diğerleri, 2008). (Laboratuvar sonrası- okuma ve yansıtma kısımları).

\subsubsection{Kontrol Grubunda Geleneksel Yaklaşımının Uygulanma Süreci}

Kontrol grubunda, öğrencilerin de uygulamalara katıldı̆ı ancak ağırlıklı olarak öğretmen merkezli bir öğretim yapılmıştır. Sınıftaki en önemli materyal ders kitabı ve öğretmenin öğrencilere dağıttığı test yapraklarıdır. Kontrol grubundaki öğrencilerle, ATBÖ grubundaki öğrencilere aynı konularda etkinlikler yapılmıştır, ancak kontrol grubundaki öğrencilerin yaptıkları etkinliklerde geleneksel laboratuvar yaklaşımı (ispat yaklaşımı) kullanıımıştır (bakınız Tablo 6). Bu bağlamda, öğrenciler etkinliklerde derste öğrendikleri bilgilerin ispatını yapmıştır. Öğretmen yapılan etkinliklerin amacını ve yöntemini anlatmıştır, bazılarını sınıf tahtasına not etmiştir. Öğrencilerden 4-5 kişilik gruplar halinde çalışması ve anlatılan yöntemi basamak basamak uygulamaları istenmiştir.

Kontrol grubundaki etkinliklerin uygunlanma süreci örnek bir etkinlik üzerinden anlatılıcak olursa, örneğin, maddede Isı iletimi konusunda yapılan deneyde, deneyin amacının "Isının maddede taneciklerin titreşimi yoluyla aktarıldığını kavramak" olduğu ifade edilmiştir. Deneyle ilgili materyaller (mum, ispirto ocağı, plastik bıçak, destek çubuğu, üç ayak, toplu iğne vs) grupların 
masalarına bırakılmıştır. Öğretmen, bu materyalleri nasıl kullanacaklarını anlatmış, öğrencilerin düzenekleri kurmalarına yardımcı olmuş ve deneyi nasıl yapacağını basamak basamak anlatmıştır. Bu bağlamda öğrencilere, plastik bıçakla mumları eşit büyüklükte kesmeleri gerektiği ve bakır teli bunların ortalarından geçirerek eşit uzaklıkta tele yerleştirmeleri gerektiği anlatılmıştır. Sonra deneyin şekli öğretmen tarafından sınıf tahtasına çizilmiştir. Öğrencilerden telin bir ucundan ısıtıldığında ne olacağını tahmin etmelerini ve bu tahminlerini gerekçeleriyle birlikte defterlerine yazmaları istenmiştir. Ayrıca, bakır teli ısıtmaya başladıktan sonra mumlara ne olduğu ile ilgili gözlemlerini de defterlerine yazmaları istenmiştir. Öğretmen, etkinlikler esnasında sınıf içerisinde gezinmiş ve öğrencilere "Isınan teldeki muma ne oldu? tahminleriniz ve gözlemleriniz birbirini destekledi mi? ISı maddede nasıl iletilir? şeklinde sorular sormuş, öğrencilerden soruların cevaplarını almış ve bu cevapları değerlendirmiştir. Bazı yerlerde öğrencilerin sorduğu sorulara direk cevap vermiştir. Etkinlik bittikten sonra öğrencilerin etkinlikte yaptıklarını raporlaştırmaları istenmiştir ve konuyla ilgili test soruları çözülmüştür. Öğrenciler, yaptıklarını raporlaştırırken geleneksel laboratuvar rapor formatının kısımları olan "amaç, deneyin yapııışı, gözlemler ve veriler, sonuçlar ve tartışma" kullanmıştır.

\section{BULGULAR}

Bu kısımda araştırmanın birinci ve ikinci problemlerinden elde edilen bulgulara yer verilecektir.

\subsection{Birinci Araştırma Probleminden Elde Edilen Bulgular}

Araştırmanın birinci sorusunda deney ve kontrol gruplarında yer alan öğrencilerin kavramsal anlamaları arasında istatistiksel olarak herhangi bir farklılık olup olmadığı araştırılmaya çalışıımıştır. Bu bağlamda, öncelikle deney ve kontrol grupları arasında ön test puanlarına göre anlamlı bir farklılık olup olmadığını Kruskal Wallis testi kullanılarak belirlenmiştir. Deney ve kontrol gruplarının ön test puanları arasında herhangi bir farklılık olup olmadı̆̆ı Tablo 7'de gösterilmiştir.

Tablo 7. Kontrol ve Deney Gruplarının Ön Test Ortalama Puanlarının Karşılaştııılması

\begin{tabular}{lllllll}
\hline Gruplar & $\mathrm{N}$ & $\begin{array}{l}\text { Sira } \\
\text { ortalaması }\end{array}$ & sd & $\chi^{2}$ & $\mathrm{P}$ & $\eta^{2}$ \\
\hline Kontrol & 43 & 44.34 & 1 & 0.5 & 0.47 & 0.07 \\
Deney & 41 & 40.57 & & & &
\end{tabular}

Tablo 7'ye göre, gruplardaki öğrencilerin ön test puanlarının ortalamaları arasında anlamlı bir farklılık olmadığı için grupların birbirine denk olduğu söylenebilir $\chi^{2} \quad(s d=1, n=84)=0.5, p>.05$; $\eta^{2}=0.07$ ). Birinci probleme cevap bulabilmek için ön testler arasında herhangi bir farklılık olup olmadığı belirlendikten sonra, deney ve kontrol grupları öğrencilerinin son test puanları arasında herhangi bir anlamlı fark olup olmadığına bakılmıştır. Bu amaçla Kruskal Wallis testi kullanılmıştır. Deney ve kontrol gruplarının son test puanları arasında herhangi bir farklılık olup olmadığı Tablo 8'de gösterilmiştir.

Tablo 8. Kontrol ve Deney Gruplarının Son Test Ortalama Puanlarının Karşılaştırılması

\begin{tabular}{lllllll}
\hline Gruplar & $N$ & $\begin{array}{l}\text { Sira } \\
\text { ortalaması }\end{array}$ & sd & $\chi^{2}$ & $\mathrm{P}$ & $\eta^{2}$ \\
\hline Kontrol & 43 & 26.34 & 1 & 38.71 & 0.00 & 0.67 \\
Deney & 41 & 59.45 & & & & \\
\hline
\end{tabular}

Analiz sonuçlarına göre kontrol ve deney gruplarındaki öğrencilerin son test ortalamaları arasında anlamlı bir farklılık vardır $\left.\chi^{2}(s d=1, n=84)=38.71, p<.05 ; \eta^{2}=0.67\right)$. Diğer bir deyişle öğrencilerin ortalama son test puanları gruplara göre değişmektedir. Tablo 8'de yer alan etki büyüklüğü eta kare $\left(\eta^{2}\right) 0.67$ olarak hesaplanmıştır. Bu değer geniş etki büyüklüğünü işaret etmektedir. Grupların son test ortalama puanlarında gözlenen varyansın \%67'sinin gerçekleştirilen uygulamalardan, yani ATBÖ yaklaşımından kaynaklandığı söylenebilir. 


\section{2 İkinci Araştırma Probleminden Elde Edilen Bulgular}

İkinci araştırma probleminde deney ve kontrol gruplarındaki öğrencilerin özet yazma etkinliklerinin ortalamaları arasında herhangi bir farklılık olup olmadığı araştırılmıştır. Bu bağlamda, deney ve kontrol gruplarındaki özet yazma etkinlikleri açısından herhangi bir anlamlı farklıık olup olmadığına bakılmıştır. Bunun için Kruskal Wallis testi kullanılmıştır. Bu problemden elde edilen sonuçlar Tablo 9'da sergilenmiştir.

Tablo 9. Kontrol ve Deney Gruplarının Özet Yazma Etkinliklerinin Ortalama Puanlarının Karşılaştırılması

\begin{tabular}{lllllll}
\hline Gruplar & $N$ & $\begin{array}{l}\text { Sira } \\
\text { ortalaması }\end{array}$ & sd & $\chi^{2}$ & $P$ & $\eta^{2}$ \\
\hline Kontrol & 43 & 25.97 & 1 & 40.67 & 0.00 & 0.69 \\
Deney & 41 & 59.84 & & & & \\
\hline
\end{tabular}

Tablo 9'da görüldüğü gibi grupların özet yazma etkinliklerinin ortalama puanları gruplara göre anlamlı olarak değişmektedir. $\left.\chi^{2}(s d=1, n=84)=40.67, p<.05 ; \eta^{2}=0.69\right)$. Gruplardaki öğrencilerin özet yazma etkinliklerinin puanlarının ortalamaları arasındaki farklılık deney gruplarının lehine anlamlı olarak değişmektedir. Tablo 9'da deney ve kontrol grubu öğrencilerinin özet yazma etkinlik puanlarına ilişkin eta kare değeri $\left(\eta^{2}\right) 0.69$ olarak hesaplandığı görülmektedir. Bu eta kare değeri, geniş düzeyde bir etki büyüklüğünü işaret etmektedir. Buna göre, deney ve kontrol grubu öğrencilerinin özet yazma etkinliği puanlarına ait varyansın \%69'unun ATBÖ yaklaşımından kaynaklandığı yorumu yapılabilir.

\section{SONUÇ, TARTIŞMA VE ÖNERILER}

Bu çalışma ile, ortaokul 6. sınıf madde ve ısı ünitesi konusunda öğrencilerin yazmış oldukları argümantasyon ve özet yazma (açıklamaya dayalı yazma) etkinliklerinin öğrencilerin kavramsal anlamaları üzerindeki etkisi incelenmiştir. Çalışma sonucunda, argümantasyona dayalı yazma etkinliklerinin öğrencilerin kavramsal anlamalarını geliştirmede geleneksel yönteme göre istatistiksel olarak daha etkili olduğu ve deney grubundaki öğrencilerin kontrol grubundaki öğrencilerden istatistiksel olarak daha iyi özet yazma etkinlikleri yaptıkları görülmektedir.

Tablo 7 ve 8 incelendiğinde, deney ve kontrol grupları arasında ön test puanlarının ortalamaları arasında herhangi bir farklılık ortaya çıkmazken $\left(\chi^{2}(s d=1, n=84)=0.5, p>.05\right)$, son test puan ortalamalarında deney grubu lehine anlamlı bir farklılık ortaya çıkmıştır $\left(\chi^{2}(s d=1, n=84)=38.71\right.$, p>.05). Aradaki bu farkın ATBÖ yaklaşımından kaynaklandığı ve ATBÖ yaklaşımının öğrencilerinin kavramsal anlamalarını olumlu yönde etkilediği söylenebilir. Illgili alan yazın incelendiğinde, fen eğitiminde argümantasyona dayalı yazma etkinliklerinin öğrencilerin kavramsal anlamalarına not alma vb geleneksel yöntemle yapılan yazma etkinliklerinden daha iyi öğrenmeyi sağladığı vurgulanmıştır (Chen ve diğerleri, 2013; Hand ve diğerleri, 2004). Ayrıca, ATBÖ yaklaşımının ve geleneksel yöntemin karşılaştırıldığı çalışmalarda, ATBÖ yaklaşımıyla öğrenim gören öğrencilerin kavramsal anlamalarının geleneksel yöntemle öğrenim gören öğrencilerden istatistiksel olarak iyi olduğu rapor edilmiştir (Günel ve diğerleri, 2010; Hand ve diğerleri, 2004, 2018; Hohensell ve Hand, 2006; Kıngır ve diğerleri, 2012; 2013; McDermott ve Hand, 2010). Bu bağlamda, elde edilen sonucun alanyazın ile uyumluolduğu görülmektedir. ATBÖ yaklaşımında öğrenciler, eğitimden önce, eğitim esnasında ve eğitimden sonra yazma etkinlikleriyle meşgul olmaktadır (Wallace ve Hand, 2007). Eğitimden önce öğrenciler, kendi başlangıç sorularını belirlemekte ve bu sorularına cevap olacak yöntemi yazmaktadır. Eğitim esnasında, deneylerinden elde ettikleri veri ve gözlemlerini yazmakta ve bunlara bağlı olarak iddia ve kanıtlarını oluşturmaktadır. Eğitim sonunda ise farklı kaynakları okumakta ve oradaki bilgilerle kendi bilgilerini karşılaştırmakta ve öğrenme sürecinde elde ettiklerini yansıtmaktadır. ATBÖ yaklaşımının, yansıtma kısmı öğrencilere başlangıçtaki fikirlerini ve deney etkinlikleri vasıtasıyla öğrendiklerini karşılaştırma fırsatı 
vermektedir (Hand ve diğerleri, 2004, 2018; Jang ve Hand, 2017; Yaman, 2018a, 2018b). Bu yazma etkinlikleriyle, öğrenciler önceki bilgilerini yeni bilgileriyle bağlantılama olanağı kazanmış, bunun sonucunda ise çalışılan konuyla ilgili daha derinlemesine düşünme ve anlama imkanı kazanmış olabilir. Ayrıca, okuma ve yansıtma kısmında öğrenciler alan bilgilerini zihinlerinde oturtabilmeleri için karşılaştırma ve uzlaştırma imkanı bulmuş olabilirler. Bu durum önemlidir çünkü, öğrenciler bu şekilde hem argümantasyon (uzlaşmaya nasıl varacakları) yoluyla elde ettikleri bilgileri hem de ürün (uzlaşmaya varılmış alan bilgisi) olan bilgileri anlamaları gerekir. Böylelikle öğrenciler, farklı kaynakları araştırarak kendi fikirlerini doğrulama ya da çürütme imkanı bulmaktadır (Jang ve Hand, 2017).

Ayrıca, öğrenciler ATBÖ yaklaşımının öğrenme ortamında grup ve sınıf tartışması yapmaktadır. Öğrencilerin kendi başlangıç sorularını inceleme fırsatı verilmekte ve yaptıkları araştırmalara dayanarak kendi iddialarını ve kanıtlarını oluşturmaları konusunda cesaretlendirilmektedir. ATBÖ yaklaşımında soru, iddia ve kanıt argümantasyon bileşenleridir ve kanıt veriden farklıdır. Bir şeyin kanıt olarak sayılabilmesi için verinin gerekçelendirilmesi gerekmektedir. Yapılan araştırmalar argümantasyonun öğrencilerin iletişim, kritik düşünme becerisi zihinsel ve üst bilişsel becerilerini ve gerekçelendirme yeteneğini geliştirmesinden dolayı, öğrencilerin bilgilerini oluşturabilmesi ve bilginin ilerleyebilmesi için argümantasyon sürecine katılması gerektiğini ifade etmektedir (Cavagnetto, 2010). Bu bağlamda, ATBÖ yaklaşımıyla öğretim yapan öğrenciler bu süreçlere katıldıkları için bu öğrenme ortamı onların kavramsal anlamalarının oluşmasına yardım etmiş olabilir.

Tablo 9 incelendiğinde, ATBÖ yaklaşımıyla öğrenim gören öğrencilerin geleneksel yönteme göre öğrenim gören öğrencilerden özet yazma etkinliklerinde daha iyi olduklarını göstermektedir $\left(\chi^{2}\right.$ $(s d=1, n=84)=40.67, p<.05)$. Hohensell ve Hand (2006) yaptıkları çalışmada geleneksel yöntem ve ATBÖ yaklaşımını uygulayan öğrencilere özet yazma etkinlikleri yaptırmıştır. Çalışma sonucunda, argümantasyona dayalı yazma etkinliklerinden sonra ATBÖ ve geleneksel yöntemdeki öğrencilerin kavramsal anlamaları arasında istatiksel olarak anlamlı bir fark bulunmazken, özet yazma etkinliklerinden sonra ATBÖ grubundaki öğrencilerin istatistiksel olarak daha anlamlı kavramsal anlamaya sahip oldukları ortaya çıkmıştır. Yapılan bu çalışmada ise, ATBÖ grubundaki öğrenciler hem argümantasyona dayalı yazma etkinlikleri hem de özet yazma etkinliklerinde kontrol grubundaki öğrencilere göre istatistiksel olarak daha anlamlı kavramsal anlamaya sahip oldukları belirlenmiştir. Bunun nedeni öğrencilerin argümantasyona dayalı yazma etkinliklerindeki inşa ettikleri fikirleri kullanarak özet yazma etkinliklerini yapmaları olabilir (Jang ve Hand, 2017); çünkü, ATBÖ yaklaşımındaki yazma etkinliklerinin amacı geleneksel yöntemdeki rapor yazımından farkııır. ATBÖ yaklaşımındaki amaç, başlangıç sorularının, iddia ve kanıtları belirleyerek bilimsel argümantasyon yapmak iken geleneksel yöntemdeki amaç, sonuç ve tartışmayı kullanarak bir deneyin sonucunu rapor etmektir. Ayrıca, bu durum ATBÖ grubundaki öğrencilerin her iki yazma etkinliklerini birbirinin tamamlayıcısı gibi görürken, geleneksel yöntemdeki öğrencilerin bu iki yazma etkinliğini birbirinden farklı olarak görmüş olmalarından kaynaklanabilir (Hohensell ve Hand, 2006).

İlgili alanyazın incelendiğinde, öğrenme amaçlı yazma etkinlikleri öğrencilerin kavramsal anlamalarını artırdığı, özellikle yaşça genç bir muhatapa yazılan yazma etkinliklerinin öğretmene ya da ebeyne yazılan yazma etkinliklerinden istatiksel olarak daha etkili olduğu sonucu ortaya çıkmıştır (Günel, Hand ve McDermott, 2009; Günel, Hand ve Prain, 2007). Ayrıca, Günel, Hand ve Prain (2007) öğrenme amaçlı yazma etkinlikleriyle öğrencilerin bilgileri farklı şekilde sergileme imkanıbulduklarını, geleneksel yazma etkinliklerinde bilginin tekrarının yapılma eğiliminde olduğunu rapor etmiştir. Son yıllarda nerofizyoloji alanında yapılan çalışmalar sonucunda da özet yazma etkinliğinin argümantasyona dayalı yazma etkinliklerinden daha fazla zihinsel bir çaba gerektirdiği ortaya konulmuştur (Lamb, Hand ve Yoon, 2017). Bunun sebebinin öğrencilerin, öğrenme amaçlı yazma etkinliklerinde, öğretmenden farklı bir muhataba yazdıklarında bir dizi dil transfer süreci gerçekleştirmeleri olabileceği düşünülmektedir. Prain ve Hand (2005) bu dil transfer 
süreçlerini, günlük dil, fen dili ve muhatabın dili olarak belirtmiştir. Bu bağlamda, öğrenciler fen dilini kendilerinin anlayabileceği günlük dile, sonrasında bu dili muhataplarının anlayabilmesine olanak sağlamak ve açıklama yapabilmek amacıyla muhatap diline çevirmektedir. Bu çeviri süreçleri, öğrencinin içerik bilgisiyle meşgul olmasını, yazmaları istenilen dil öğeleriyle çerçevelendirmelerini ve muhatablarını gözönünde bulundurarak yazılı söylemlerini sergilemelerini gerektirmektedir (Günel ve diğerleri, 2009). Böylelikle öğrenciler, yazar olarak, bilgiyi daha öncekinden farklı bir şekilde inşa etmektedir (Galbraight, 1999).

Bu çalışmadan yola çıkılarak, ATBÖ yaklaşımının fen derslerinde farklı sınıf seviyelerinde daha uzun süreli ve birden fazla konuyu kapsayan çalışmalarda kullanılması önerilmektedir. Bu çalışmada, özet yazma etkinliği olarak mektup türü tercih edilmiştir. Benzer çalışmalarda poster, gezi yazısı, hikaye, şiir, günlük tutma vb gibi yazma türleri seçilerek bunların sonuçları incelenebilir. Ayrıca, öğrencilerin yazma etkinliklerinde kullandıkları çoklu gösterimler incelenerek bu gösterimlerin öğrencilerin kavramsal anlamalarına herhangi bir etkisi olup olmadığı araştırılabilir.

\section{Kaynakça}

Aktamış, H. ve Hiğde, E. (2015). Fen eğitiminde kullanılan argümantasyona modellerinin değerlendirilmesi. Mehmet Akif Ersoy Üniversitesi Eğitim Fakültesi Dergisi, 35, 136-172.

Bereiter, C. ve Scardamalia, M. (1987). The psychology of written composition. Hillsdale, NJ: Lawrence Erlbaum Associates.

Burke, K. A., Greenbowe, T. J. ve Hand, B. M. (2005). Excerpts from The process of using inquiry and the science writing heuristic. Prepared for the Middle Atlantic Discovery Chemistry Program, Moravian College, Bethlehem, PA.

Büyüköztürk, Ş. (2018). Sosyal bilimler için veri analizi el kitabı: istatistik, araştırma deseni, SPSS uygulamaları ve yorum (24. bas.). Ankara: Pegem Yayınları

Cavagnetto, A. R. (2010). Argument to foster scientific literacy: A review of argument interventions in $\mathrm{K}-12$ science contexts. Review of Educational Research, 80(3), 336-371.

Cavagnetto, A. R. ve Hand, B. (2012). The importance of embedding argument within science classrooms. In M. S. S. Khine (Ed.), Perspectives on scientific argumentation (pp. 3953). Dordrecht, the Netherlands: Springer.

Chen, Y. C., Hand, B. ve McDowell, L. (2013). The effects of writing-to-learn activities on elementary students' conceptual understanding: Learning about force and motion through writing to older peers. Science Education, 97(5), 745-771.

Choi, A., Hand, B. ve Greenbowe, T. (2013). Students' written arguments in general chemistry laboratory investigations. Research in Science Education, 43(5), 1763-1783.

Driver, R., Newton, P. ve Osborne, J. (2000). Establishing the norms of scientific argumentation in classrooms. Science Education, 84, 287-312.

Duschl, R. A. (2007). Quality argumentation and epistemic criteria. S. Erduran ve M. P. JimenezAleixandre (eds.) in Argumentation in Science Education (s. 159-175). Springer.

Emig, J. (1977). Writing as a mode of learning. College Composition and Communication, 28(2), 122128.

Ford, M. J. ve Forman, E. A. (2006). Redefining disciplinary learning in classroom contexts. In J. Green ve A. Luke (Eds.), Review of educational research (Vol. 30, pp. 1 - 32). Washington, DC: American Education Research Association.

Galbraith, D. (1999). Writing as a knowledge-constituting process. In D. Galbraith ve M. Torrance (Ed.), Knowing what to write: Conceptual processes in text production (pp. 139159). Amsterdam, the Netherlands: Amsterdam University Press. 
Gunel, M. Hand, B. ve Prain V. (2007). Writing for Learning in Science: A Secondary Analysis of Six Studies. International Journal of Science and Mathematic Education, 5, 615-637.

Gunel, M., Kabatas-Memis, E. ve Buyukkasap, E. (2010). Effects of the science writing heuristic approach on primary school students' science achievement and attitude toward science course. Education in Science, 35(155), 49-62.

Gunel, M., Hand, B., ve McDermott, M. A. (2009). Writing for different audiences: Effects on highschool students' conceptual understanding of biology. Learning and Instruction, 19, 354-367.

Hand, B. (2017). Exploring the role of writing in science: A 25-year journey. Literacy Learning: the Middle Years, 25(3), 16-23.

Hand, B. Shelley, M. C, Laugerman, M., Fostvedt, L. ve Therrien, W. (2018). Improving critical thinking growth for disadvantaged groups within elementary school science: A randomized controlled trial using the ScienceWriting Heuristic approach. Science Education;1-18. https://doi.org/10.1002/sce.21341

Hand, B., Norton-Meier, L. ve Jang, J. (Eds.) (2017). More voices from the classroom: International teachers' experience with Argument-Based Inquiry. Rotterdam: Sense Publishers.

Hand, B., McDermott, M. ve Prain, V. (2016). Using multimodal representations to support learning in the science classroom. Switzerland: Springer International Publishing.

Hand, B., Wallace, C. ve Yang, E. (2004). Using the science writing heuristic to enhance learning outcomes from laboratory activities in seventh grade science: Quantitative and qualitative aspects. International Journal of Science Education, 26, 131-149.

Hand, B. ve Prain, V. (2006). Moving from border crossing to convergence of perspectives in language and science literacy research and practice. International Journal of Science Education, 28(2-3): 101-107.

Hand, B. ve Keys, C. W. (1999). Inquiry investigation: a new approach to laboratory reports. The Science Teacher, 66(4), 27-29.

Hohenshell, M. L. ve Hand, B., (2006). Writing-to-learn strategies in secondary school cell biology: A mixed method study. International Journal of Science Education, 28(2), 261-289.

Jang, J. ve Hand, B. (2017). Examining the value of a scaffolded critique framework to promote argumentative and explanatory writings within an argument-based inquiry approach. Research in Science Education, 47(6), 1213-1231.

Kıngır, S., Geban, Ö. ve Günel, M. (2012). How does the science writing heuristic approach affect students' performances of different academic achievement levels? A case for high school chemistry. Chemistry Education Research and Practice, 13, 428-436.

Kıngır, S., Geban, Ö. ve Günel, M. (2013). Using the science writing heuristic approach to enhance student understanding in chemical change and mixture. Research in Science Education, 43, 16451663.

Lamb, R. L., Hand, B. M. ve Yoon, S. (2017). Examinations of cognitive processing of science writing tasks. Journal of Psychology and Brain Studies, 1, 1-5.

McDermott, M. A. ve Hand, B. (2010). A secondary reanalysis of student perceptions of nontraditional writing tasks over a ten year period.Journal of Research in Science Teaching, 47(5), 518-539.

Merriam, S. B. (2009). Qualitative research: A guide to design and implementation. San Francisco: Jossey-Bass.

Norris, S. P. ve Phillips, L. M. (2003). How literacy in its fundamental sense is central to scientific literacy. Science Education, 87, 224-240.

Norton-Meier, L., Hand, B., Hockenberry, L. ve Wise, K. (2008). Questions, claims, and evidence: The important place of argument in children's science writing. Portsmouth, $\mathrm{NH}$ : Heinemann. 
Prain, V. (2006). Learning from writing in secondary science: Some theoretical and practical implications. International Journal of Science Education, 28(2-3), 179-201.

Sampson, V. ve Clark, D. (2006). Assessment of argument in science education: A critical review of the literature. In Proceedings of International Conference of the Learning Sciences 2006, Bloomington, IN. (pp. 655-661).

Wallace, C. S. ve Hand, B. (2007). Using a science writing heuristic to promote learning from laboratory. In C. S. Wallace, B. Hand ve V. Prain (Ed.), Writing and learning in the science classroom (pp. 67-89). Dordrecht, The Netherlands: Springer.

Yaman, F. ve Ayas A. (2015). Assessing changes in high school students' conceptual understanding through concept maps before and after the computer-based predict-observe-explain (CB-POE) tasks on acid-base chemistry at the secondary level, Chemistry Education Research and Practice, 16(4), 843-855.

Yaman, F. (2018a). Effects of the science writing heuristic approach on the quality of prospective science teachers' argumentative writing and their understanding of scientific argumentation. International Journal of Science and Mathematics Education, 16(3), 421-442.

Yaman, F. (2018b). Pre-service science teachers' development and use of multiple levels of representation and written arguments in general chemistry laboratory courses. Research in Science Education, https://doi.org/10.1007/s11165-018-9781-0

Yore, L. D., Florence, M. K., Pearson, T. W. ve Weaver, A. J. (2006). Written discourse in scientific communities: a conversation with two scientists about their views of science, use of language, role of writing in doing science, and compatibility between their epistemic views and language. International Journal of Science Education, 28(2-3), 109-141. 


\section{Extended Summary}

\section{Introduction}

Current efforts in science education address the need to use writing-to-learn strategies in science classrooms. Language is critical for doing science, constructing science understandings and communicating about science, in particularly written language. Argument is a means for constructing science knowledge and it is only advanced through the use of language. Research has indicated that writing-to-learn strategies can increase students' learning and conceptual understanding. However, there is a need for more empirical research on writing-to-learn strategies related to the quality of learning resulted from engaging in particular writing tasks in a situated context. Therefore, this study investigated the effect of two different writing-to-learn strategiesargumentative and summary writing- on students' conceptual understanding. The following research questions were investigated in the study:

1. Is there any statistical difference between the $6^{\text {th }}$ grade students who were implemented Science Writing Heuristic, the SWH approach and the students who were implemented traditional approach on their conceptual understanding?

2. Is there any statistical difference between the $6^{\text {th }}$ grade students who were implemented the SWH approach and the students who were implemented traditional approach on their summary writing activities?

\section{Method}

A quasi experimental, pretest-post-test design was used to address the research questions. Four intact classes taught by one science teacher from a public middle school were selected for the study. In this context, while two classes were assigned as the experimental group, the other two classes were assigned as the control group. Students in control group were instructed with traditional approach, students in experimental group were instructed by the SWH approach. The activities were performed on matter and heat unit in the curriculum of 6 grade level. $846^{\text {th }}$ graders participated the study. In this context, there were 43 (21 male and 22 female) students in control group and 41(21 male and 20 female) students in experimental group. The study lasted in five weeks.

Data included a two-tier test and a rubric. The two-tier test had 20 items related to the matter and heat unit. In the first tier of the two-tier test, a multiple-choice question was asked and in the second tier, the reason for the multiple-choice item for that question was asked. The rubric had 4 likert type including low, moderate, high, and very high scale. The data analyzed using SPSS-21.

\section{Results}

The purpose of the first research question is to determine if there is any significant difference between control and experimental groups students' pretest scores. For this purpose, Kruskal Wallis was used. The results indicated that students' pretest scores do not vary by groups $\chi^{2}(s d=1, n=84)=0.5, p>.05$. Since there is no statistically difference between students' pretest scores in all groups, it can be said that the groups are equal to each other. Moreover, in the first research question, Kruskal Wallis was used to determine if there is any significant difference between control and experimental groups students' posttest scores. The results showed that there is significant difference between control and experimental groupsstudents' posttest mean scores $\chi^{2}$ $(s d=1, n=84)=38.71$. In other words, students' posttest mean scores changed in groups.

The purpose of the second research question is to determine if any significant difference between control and experimental groups students' summary writing scores. The authors used Kruskal Wallis for this purpose. The results indicated that groups' summary writing scores changed statistically in between groups $\chi^{2}$ (sd=1, $\mathrm{n}=84)=40.67, \mathrm{p}<.05$.

\section{Discussion and implications}

This study focused on the $6^{\text {th }}$ grade students' conceptual understanding related to matter and heat unit when they were engaged with two different writing-to-learn strategies including argumentative and summary writings. The results revealed that students who were engaged in the SWH approach scored significantly higher than those engaging with science activities through traditional approach. Moreover, the students who were instructed by the SWH approach statistically performed better than those who were instructed with traditional approach in summary writing activities. In the light of the findings, the students should be provided with opportunities to help them engage with writing activities that require students to convince the others about what the conceptual ideas mean within the topic such as argumentative writing and to inform the others about these concepts and how these concepts are related to each other like summary writing activities. Long term studies can be conducted in different topics and different summary writing activities or instance, story, poem etc can be used for the studies. Moreover, students' multiple model of representations can be investigated in both argumentative and summary writing activities. 